This is a postprint (final submitted manuscript) version of the following article:

Parris, D., \& McInnis-Bowers, C. (2017). Business not as Usual:

Developing socially conscious entrepreneurs and intrapreneurs. Journal of Management Education, 41(5), 687-725. https://

doi.org/10.1177/1052562917720709

Per publisher policy, this postprint is licensed with a Creative Commons Attribution-NonCommercial-NoDerivatives 4.0 International license (CC BY-NC-ND) license.

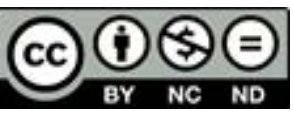




\section{Journal of Management Education}

\section{Business not as Usual: Developing Socially Conscious Entrepreneurs and Intrapreneurs}

\begin{tabular}{|c|c|}
\hline Journal: & Journal of Management Education \\
\hline Manuscript ID & JME-16-0013-ETR.R3 \\
\hline Manuscript Type: & Empirical/Theoretical/Review Articles \\
\hline $\begin{array}{r}\text { Subject Area Keywords: Please } \\
\text { select at least three subject } \\
\text { areas from the list.: }\end{array}$ & $\begin{array}{l}\text { Entrepreneurship < Strategic management }<\text { Academic Discipline/Subject } \\
\text { Areas, Sustainability < Strategic management }<\text { Academic } \\
\text { Discipline/Subject Areas, Innovation < Strategic management < Academic } \\
\text { Discipline/Subject Areas, PRME < Institutional/Field-Level Issues, Role of } \\
\text { business schools < Institutional/Field-Level Issues, Higher education }< \\
\text { Levels of Education/Teaching, Undergraduate }<\text { Levels of } \\
\text { Education/Teaching, Program development }<\text { Institutional/Field-Level } \\
\text { Issues, Servant leadership < Leadership < Academic Discipline/Subject } \\
\text { Areas, Curriculum design }<\text { Theories and Issues in Education, Teaching and } \\
\text { Learning }\end{array}$ \\
\hline \multicolumn{2}{|l|}{$\begin{array}{r}\text { Research Approach Keywords: } \\
\text { You may select as many or as } \\
\text { few as you wish.: }\end{array}$} \\
\hline Abstract: & $\begin{array}{l}\text { Our objective was to design an introductory business course to shape the } \\
\text { mindsets and skillsets of the next generation of socially conscious } \\
\text { practitioners-to help students develop a sense of self-efficacy built on the } \\
\text { confidence that they can make a positive impact on the world using } \\
\text { entrepreneurial thinking and action. Essentially, the focus was to develop } \\
\text { an introductory business course that would encourage and enable students } \\
\text { to understand that business can be a force for good (sustainability \& social } \\
\text { impact) and to practice collaborative innovation (human centered design } \\
\text { thinking). The overarching design principle was business not as usual, } \\
\text { which embraced four themes: (1) sustainability and social } \\
\text { entrepreneurship; ( } 2 \text { ) collaborative innovation; ( } 3 \text { ) entrepreneurial thinking } \\
\text { and action; and ( } 4 \text { ) self-authorship. We provide an overview of the course } \\
\text { modules and their respective learning outcomes along with details of } \\
\text { course content and activities to ensure transferability. A concluding } \\
\text { discussion shares student impact and the challenges of success. We } \\
\text { highlight how course design can be a catalyst to enable students to be the } \\
\text { change they want to see in the world. }\end{array}$ \\
\hline
\end{tabular}




\title{
Business not as Usual: Developing Socially Conscious Entrepreneurs and Intrapreneurs
}

\author{
Denise Linda Parris, Ph.D.* \\ Assistant Professor \\ The W. A. Franke College of Business \\ Northern Arizona University \\ P.O. Box 15066 \\ Flagstaff, AZ 86011-5066 \\ 352-217-6630 \\ deniselparris@gmail.com
}

\section{Cecilia McInnis-Bowers, Ph.D.}

Professor

Rollins College

1000 Holt Ave -2778

Winter Park, Florida 32789

CMcInnis-Bowers@rollins.edu

*Corresponding author 


\begin{abstract}
Our objective was to design an introductory business course to shape the mindsets and skillsets of the next generation of socially conscious practitioners - to help students develop a sense of self-efficacy built on the confidence that they can make a positive impact on the world using entrepreneurial thinking and action. Essentially, the focus was to develop an introductory business course that would encourage and enable students to understand that business can be a force for good (sustainability and social impact) and to practice collaborative innovation (human centered design thinking). The overarching design principle was business not as usual, which embraced four themes: (1) sustainability and social entrepreneurship; (2) collaborative innovation; (3) entrepreneurial thinking and action; and (4) self-authorship. We provide an overview of the course modules and their respective learning outcomes along with details of course content and activities to ensure transferability. A concluding discussion shares the impact on students and the challenges of success. We highlight how course design can be a catalyst to enable students to be the change they want to see in the world.
\end{abstract}

\begin{abstract}
Keywords principles for responsible management education (PRME), servant leadership, sustainability, social entrepreneurship, business education, collaborative innovation, design thinking, entrepreneurial thinking and action, effectuation, self-authorship
\end{abstract}




\section{Introduction}

Business schools have been criticized for failing to provide employers and society with graduates capable of thinking and acting in holistic terms with an emphasis on entrepreneurship, ethics, leadership, corporate social responsibility, cultural awareness, cultural intelligence, and sustainability (Persons, 2012; Tekarslan \& Erden, 2014). Executives highlight the need to teach students how they can function as entrepreneurs both inside and outside companies while focusing on how business should be a force for good instead of just making business 'less bad' (Bradfield, 2009).

A business that is a force for good practices sustainability and social impact by creating "more profit for the company and more social, economic, and environmental prosperity for society" (Savitz \& Weber, 2006, p. xi). Forward thinking business education will go beyond profit seeking by enabling students to practice sustainability and create social impact.

The resulting effect of 'usual' business education has been a lack of innovation, problem solving, and critical thinking skills (Thomas, Lee, Thomas, \& Wilson, 2014). Ethical lapses in business, the recent financial crisis, climate change, human rights, and gender equality (das Neves \& Vaccaro, 2013; Doorey, 2011; Frynas, 2010; Lazarus \& McManus, 2006; Makary, 2012) have further called into question business schools' ability to develop students' values and ethical decision making skills (Bergman, Westerman, Bergman, Westerman, \& Daly, 2013; Crossan, Mazutis, Seijts, \& Gandz, 2013). These critiques are noted in the words of practitioners, academics, and students.

For instance, at the 2013 Ashoka U Exchange, an organization that works with higher education institutions to foster social innovation, the role of business was challenged. One of the session presenters, a faculty member, boldly put forward business education was counterproductive by citing the number of businesses that fail each year. His solution was the Business Canvas Model (Blank, 2013), a one page hand-out that he distributed to aspiring social entrepreneurs - individuals who seek business solutions to provide social value, economic development, and environmental 
sustainability (Mair \& Marti, 2006). He touted that students can simply fill in the blanks to create their businesses (personal observation, February 21, 2013). Voilà! Business education is unnecessary.

However, at that same conference, we utilized a marketing data collection method, called intercept-interviews, where students from higher education institutions across the United States were intercepted before or after conference sessions and during breaks and asked: Why do you want to be a social entrepreneur? What is it that you need to know to move your idea forward? How are you learning what you need? Student after student echoed they did not feel they were learning the necessary skills and mindsets to make their social venture a reality. A female student at a top program shook her head as she said:

I am so frustrated. I know my idea is good. I need to understand marketing and reaching customers. My school doesn't teach that. We have parents whose students attend our college come and do lunch-chats on how they do marketing where they work. I need so much more (personal communication, February 22, 2013).

Students seeking high impact careers that change the world know business knowledge is a requisite to success.

In response to literature trends, discussions at conferences, and our own experiences with students, we designed a new introductory business course to develop responsible business leaders and social entrepreneurs. Our approached aligned with Viswanathan's (2012) philosophical orientation of encouraging and enabling students to envision a better world and Bradfield's (2009) emphasis on developing students' ability to address sustainability by embracing the triple bottom-line of planet, people, and profit (Elkington, 1998) as a core business practice. Our objective was to develop socially conscious practitioners - individuals committed to using business as a powerful force for doing good, both inside existing organizations and as creators of new organizations solving business and social problems. We recognized the growing expectations for sustainability, the critiques of business 
education, and the emergence of social entrepreneurship that are reframing business education as a force for good.

Thus, our design principle was business not as usual through embracing four themes: sustainability and social entrepreneurship; collaborative innovation — a process of sharing ideas, information, and work to develop novel ideas, products, services, processes, and business models (Brown, 2008, 2009; D.school, 2013); entrepreneurial thinking and action - the process of creating something from nothing (Baker \& Nelson, 2005; Di Domenico, Haugh, \& Trace, 2010; Sarasvathy, 2001); and self-authorship — the authentic assertion of self-perspectives and an internalized moral compass (Hodge, Baxer, \& Haynes, 2009). We embraced learning as a process (Allan, 2012; Evans, 1998; Oliver \& Gersham, 1989; Whitehead, 1929) with a critical theory perspective (Kearins \& Delyse, 2003; Viswanathan, 2012) by designing the course as a fast-paced immersion into content that challenges students to explore the pros and cons of current business practices while imagining possibilities for change. Students learn how business can be a world change agent for good (Bradfield, 2009). In order to gain this knowledge from the course students must: actively be involved in the experience; reflect on the experience; conceptualize the experience; and apply the new knowledge gained from the experience (Kolb, 1984; Moon, 2013). The course design aligns with the entrepreneurial advice of 'fail fast, early, and often,' and 'leverage it' (Gartner \& Ingram, 2013; Olaison \& Sørensen, 2014). Throughout the course students are encouraged to question the status quo and to foster an ethical commitment to society and the planet.

This paper presents the design of an introductory business course that supports the next generation of socially conscious business students to be responsible business leaders and social entrepreneurs. Essentially, the focus was on developing an introductory business course that would encourage and enable students to understand that business can be a force for good (sustainability and social impact) and to practice collaborative innovation (human centered design thinking). To do this, 
we first discuss trends and literature that led to the selection of the themes and the choice of pedagogies integrated throughout the course. Secondly, we describe the design and delivery of the new BUS 101-Business, Innovation \& Entrepreneurial Thinking to ensure transferability. A concluding discussion shares the impact on students and the challenges of success. Our aim is to inspire educators to see course design as a catalyst to encourage and enable students to be the change they want to see in the world.

\section{Impetus for Business Not as Usual}

In response to changing times, we developed an introductory business course for the next generation of socially conscious practitioners. Our design principle was business not as usual. Next, we will briefly review the generational values of business students, the expectation that successful businesses practice sustainability, the critiques of business education, and the emergence of social entrepreneurship, which were the key forces that inspired us to create something new.

\section{Generational Values of New Business Students}

We understood from the intercept interviews conducted with students at Ashoka U Exchange in 2013 that aspiring responsible business leaders and social entrepreneurs were seeking business knowledge and skillsets to make our communities a better place. A national survey by Net Impact, a leading nonprofit that empowers students to drive social and environmental change, reported that $73 \%$ of undergraduates believed that responsible business practices can lead to business profits and that $96 \%$ rank ethical behavior as a necessary quality in a leader, but only a quarter (24\%) think business leaders demonstrate it (Net Impact, 2010). Notably, 92\% of our students self-identified as leaders who will improve the world's social or environmental challenges, compared with $74 \%$ nationally (internal survey, 2013; Net Impact, 2010). These studies illustrate that a significant number of undergraduate students have higher expectations for the role of business in society and intend to fulfill those expectations by seeking socially responsible employment. With this in mind, we sought to better 
understand how the expectations for business success were changing to address the triple bottom line.

\section{Sustainability Expectations for Successful Businesses}

Business, holistically, is now viewed as an institution of and in society, with responsibilities to the local and, at times, global community beyond the maximization of shareholder wealth. Today, many stakeholders are demanding that companies should engage in deliberate strategies to achieve sustainable solutions to social and environmental challenges (McKinsey \& Co, 2010). The conversation has been elevated from corporate social responsibility (CSR) to corporate sustainability. CSR benefits society through a variety of business strategies and tactics that range from corporate giving to implementing a friendlier environmental strategy (i.e., a green initiative). Often CSR stops short by focusing largely on a company's compliance with legal-external expectations; corporate sustainability, in contrast, imbeds sustainability thinking deep into the corporate DNA and is viewed as a responsible and profitable way of management (UNCG, 2014). Increasing expectations are put on businesses to be socially responsible to a broader array of stakeholders, including consumers, the communities in which they produce and sell products, employees, and governments (Ballou, Heiger, \& Landes, 2006). For example, consumers are increasingly making purchasing decisions based on the company’s ‘green' impact or social responsibility (McKinsey Quarterly, 2014).

A growing trend is that organizations will be increasingly evaluated on their ethical commitment to social responsibility and environmental sustainability, in addition to their profitability (Parris, Dapko, Arnold, \& Arnold, 2016). In response, sustainability is being infused within departments and made a focus of collaboration across functional areas - marketing, production, human resources, finance - and not isolated in a single department, keeping the sustainability mindset in the forefront. Management dashboards or scoreboards are developed in support of the company's sustainability plans. Some leading companies produce an annual sustainability report, which include investment funds to support and measure sustainability. To meet these changing expectations 
sustainability must be integrated into business courses (Bradfield, 2009; Persons, 2012; PRME, 2015; Sroufe, Sivasubramaniam, Ramos, \& Saiia, 2014).

\section{Critique of Business Education: Sustainability as Minor Role}

Nevertheless, sustainability has not yet become embedded in mainstream business education, and human rights and the social dimension of sustainability have been given less attention than economic and environmental issues (Pfeffer, 2010). For instance, finance courses in business schools has been criticized for treating businesses not as social institutions for the common good but simply as vehicles for maximizing shareholder wealth (Werner \& Stoner, 2015). There is some coverage of sustainability at the MBA level (Aspen Institute Center for Business Education, 2009), but a paucity of attention given to undergraduates programs. Sustainability is merely limited to the inset boxes in disciplinary texts or elective courses. The focus in business programs is on environmental issues and does not address the broader issues of human rights and the social context (Benn \& Dunphy, 2009; Rusinko, 2010; Starik, Rands, Marcus, \& Clark, 2010). Currently, environmental and economic sustainability overshadow the human dimensions of sustainability. Business educators need to equip students with the knowledge and tools to manage in an increasingly complex world by enabling and encouraging them to explore the multifaceted repercussions of their decisions (Pfeffer, 2010) and developing their soft skills of leadership, innovation, and communication (Ingols \& Shapiro, 2014; Net Impact, 2011).

Although industry is changing, higher education institutions have been slow to address these changing expectations, despite the efforts of a few. For example, in 2007 the Principles of Responsible Management Education (PRME) were developed to lay the foundation for responsible management education by integrating the United Nations' Sustainable Development Goals into the business curriculum. However, seven years later during the $1^{\text {st }}$ regional meeting in North America, academic leaders acknowledged sustainability continued to play a marginal role in business programs and social entrepreneurship was not even on the agenda (personal observation, October 10-11, 2014). Attendee's 
highlighted the marginal role of sustainability due to the limited course materials, publishing outlets, and institutional support at all levels. To date, the majority of course materials — case studies and books - ignore the externalized costs and well-being of society and environment while focusing solely on monetization (Eisler, 2007; Engster, 2007). Specifically, academic leaders highlighted the scarcity of course materials across disciplines, the resistance by faculty to change their courses, and the lack of an incentive system under their tenure process to encourage faculty to explore marginalized topics. In addition, they lamented the limited doctoral training in sustainability and social entrepreneurship. While all attendees were there to be change makers within their institutions, the majority of conversations were examples of isolated success stories mirrored with complaints that change is hard (personal observation, October 10-11 2014).

Resistance to change is the norm, which exemplifies the gap between saying it's a good idea to implementing the change and then providing the continued support for sustained success at all levels of higher education institutions. Integrating sustainability as a core business function inside a business curriculum requires new processes and ways of communicating to multiple stakeholders at the individual (micro), organizational (meso), and societal (macro) levels. The drives of overcoming the barriers to change are students, academics, and practitioners that seek to create social value, foster economic development, and advance environmental sustainability, evidenced by the growing field of social entrepreneurship.

\section{Emergence of Social Entrepreneurship}

Despite being labeled the "new kid on the university block" (Jones, Warne, \& Kiser, 2010, p. 40), the phenomenon of social entrepreneurship, the intentional process of identifying or creating a sustainable for-profit or nonprofit venture that improves a social or environmental problem, is not new. The term, coined over 40 years ago by Banks (1972), was made popular by Bill Drayton, the founder of Ashoka, in the early 1980s. The first course in social entrepreneurship was taught by Gregory Dees at Harvard 
in 1994. Since then, it has been emergent in business schools (Byrne, 2010). However, like sustainability content in business curricula, social entrepreneurship may be offered only as an elective, rarely as a minor, and more frequently at the graduate level or housed in other disciplinary fields outside of business.

While social and market entrepreneurship both identify or create unrecognized possibilities to generate new economic opportunities, social entrepreneurs emphasize finding effective ways to positively impact a social or environmental problem. We embrace the broad definition of social entrepreneurship proposed by Mair and Marti (2006, p. 37):

First, we view social entrepreneurship as a process of creating value by combining resources in new ways. Second, these resource combinations are intended primarily to explore and exploit opportunities to create social value by stimulating social change or meeting social needs. And third, when viewed as a process, social entrepreneurship involves the offering of services and products but can also refer to the creation of new organizations. Importantly, social entrepreneurship, as viewed in this article, can occur equally well in a new organization or in an established organization, where it may be labeled 'social intrapreneurship.' Like intrapreneurship in the business sector, social intrapreneurship can refer to either a new venture creation or an entrepreneurial process innovation.

Students drawn to social entrepreneurship state that they feel a sense of agency to be change-makers and believe it is essential for organizational success to have a positive impact on communities, the planet, and the world (Martin \& Osberg, 2007). We highlight the entrepreneurial process is not linear and being a change-maker can be accomplished by first doing well, and then good or vice versa. For instance, in the case of Clean the World, a social enterprise that recycles soap from the hospitality industry, the founders' original intent was to make a profit by taking advantage of the political and business climate favoring environmental sustainability. To their surprise, they found their business 
model addressed a social need—reducing waste and improving hygiene in developing countries (Parris \& McInnis-Bowers, 2014).

In the early stages of innovation, the challenge of creating something from nothing and the process of "making do with what is at hand"—-social bricolage (Lévi-Strauss, 1967: 17)—exemplifies entrepreneurial thinking and action (Baker \& Nelson, 2005; Di Domenico, Haugh, \& Tracey, 2010). Next, when a social entrepreneur or practitioner imagines different possibilities and takes action on what they can afford, they may encounter surprises (Sarasvathy, 2001) along the entrepreneurial path that can lead them in different directions than originally intended. As we recognized this reality, we set out to develop a socially conscious introductory business course that embraces multiple paths.

\section{Developing a Socially Conscious Introduction to Business Course}

After an extensive literature review, exploration of leading trends, and conversations with undergraduate students, we developed an introductory business course infused with four themes: (1) the three pillars of sustainability and social entrepreneurship; (2) collaborative innovation; (3) entrepreneurial thinking and action; and (4) self-authorship. Implementing these four themes led to the development of five unique learning modules: (1) Rethinking Business as a Force for Good in the World—-sustainability and social entrepreneurship; (2) Developing Business Knowledge through Practice_-making management decisions while competing; (3) Developing Entrepreneurial Mindsets \& Processes - collaborative innovation through human centered design thinking (HCDT); (4) Identifying and Creating Opportunities — application of effectuation; and (5) "DiscoveryU"_-a selfexploration into personal knowledge and self-authorship to develop leadership. See Figure 1. Next, we briefly introduce the themes.

Insert Figure 1 


\section{The Three Pillars of Sustainability-People, Planet, Profit}

Sustainability originated in the 1980s based on the work of the Brundtland Commission (1987) that defined economic development as "meeting the needs of the present generation without compromising the ability of future generations to meet their own needs" (p. 8). In common usage, many associate it most readily with environmental causes; however, in the business context sustainability "denotes a powerful and defining idea: a sustainable corporation is one that creates profit for its shareholders while protecting the environment and improving the lives of those with whom it interacts" (Savitz \& Weber, 2006, p. xi). It operates so that its business interests and the interests of the environment and society intersect and are understood as interdependent. Sustainability thinking promotes leadership and decision-making that embrace the interdependence of all living things, all facets of society and differing aspects of the human experience (Savitz \& Weber, 2006). A commitment to sustainability not only helps people and the planet, but has resulted in higher productivity and long-term viability for organizations (McKinsey Quarterly, 2014). It is a relational rather than transactional mode of conducting business that seeks and respects multiple stakeholder perspectives and the environment. Transactional leadership focus on the exchange of resources (Bass, 1990). In contrast, we encourage and enable students to conceptualize servant leadership as a way of life rather than a management technique (Greenleaf, 1977). Servant leaders' primary motivations are service (what the leader does) and self-authorship (who the leader is); from these conscious choices of "doing" and "being" they aspire to lead (Parris \& Welty Peachey, 2012; Sendjaya \& Sarros, 2002). Service involves helping people and the planet, which starts with the internal process (Wood \& Dibben, 2015) to embrace sustainability as a core tenet of business. To help students gain a deeper understanding from multiple stakeholder perspectives and increase their ability to create innovative business solutions to existing problems that make a profit while improving the planet and society, we incorporated collaborative innovation as our next foundational theme. 


\section{Collaborative Innovation-Human Centered Design}

Human-centered design, also known as design thinking, is a mindset, as well as a set of methods for fostering creativity and solving complex problems (D.school, 2013). The focus is on end-users-those experiencing the problem to be solved-by employing ethnographic techniques to capture their perspectives. The process is comprised of five steps: gather empathy-characterize end-user perspectives; define — reframe and scope the problem; ideate - generate multiple ideas to solve the problem; generate prototypes_construct representative mock-ups; and test—seek feedback (D.school, 2013; IDEO, 2014). Design thinking, as Tim Brown, president and CEO of IDEO, states, is a "humancentered approach to innovation that draws from the designer's toolkit to integrate the needs of people [desirability], the possibilities of technology [feasibility], and requirements of business success [viability]" (IDEO, 2014, p. 1). Design thinking encourages and enables students to seek and value multiple perspectives (Benson \& Dresdow, 2013), to include a wide array of inputs, to suspend judgment while seeking innovations in climates of uncertainty, and to embrace failure as a prescribed way of knowing and doing. It can be applied solo, but the power of collaboration innovation often increases creativity and leads to breakthrough solutions. By applying the human-centered design, students gain empathy, which enables them to envision new possibilities (Welsh \& Dehler, 2013). Through utilizing the design thinking methodology students can solve market place problems and social problems, such as access to clean water, education, health care, and more.

\section{Entrepreneurial Thinking and Action-Effectuation}

The traditional entrepreneurial process taught in business courses begins with defining a problem and then focuses on identifying effective ways to solve the problem. Sarasvathy (2001, p. 245) defined this as the causation logic (i.e. to "take a particular effect as given and focus on selecting between means to create that effect"). The entrepreneur who applies causal thinking views the world as "static, linear, and independent environments" (Sarasvathy 2001, p. 251), and assumes that the future is predictable- 
and therefore, controllable, which "does not foster questioning the status quo" (Parris \& McInnisBowers, 2014, p. 361). 'Usual' business education is grounded in causal thinking-everything that happens presupposes something from which that something follows, in accordance with a rule-and focuses on pre-set goals, expected returns, avoiding surprises, competitive analysis, and inevitable trends. If we wanted our students to be change agents we needed a different way thinking.

Effectual logic, aligned with design thinking, focuses on starting with one's means (who you are, what you can do, and whom you know) and then imagining the possibilities. It's about creating something by taking action with what you have on hand (i.e., taking "a set of means as given and focus[ing] on selecting between possible effects" (Sarasvathy, 2001, p. 245). The effectual entrepreneur's search for a business model begins first by exploring a set of available means—or resources - (bird-in-the-hand-principle), and then focusing on the downside of risk (affordable loss principle), leveraging contingences (lemonade principle), forming partnerships (patchwork quilt principle), and controlling aspects of the unpredictable future (pilot-in-the-plane principle) with the outcome of developing new markets through alliances and cooperative strategies (Sarasvathy, 2001). The effectual framework encourages and enables students to question the status quo and imagine the possibilities. The effectual logic, along with bricolage (Fisher, 2012) and improvisation, particularly fits social entrepreneurship, which emphasizes allowing solutions to emerge from within the existing setting, using the resources already available there.

Our course teaches effectual logic for starting a new venture, and causation logic for strategic management of the organization. Over time, both are required through the life-cycle of organizational development. Fostering a sense of empowerment to make change, beyond the rhetoric of "change the world," requires both imagining the possibilities and having the confidence and personal tools to make them happen. If imagining different possibilities starts with one's means, then one of the most valuable tools we can provide the next generation of socially conscious practitioners is the ability to take 
inventory, develop, and grow their resources.

\section{Self-Authorship}

A critical theme of being socially conscious is self-authorship — the ability to reflect upon one's own beliefs, identity and social relationships, and to make one's own mind up (Baxter Magolda, 2001; Kegan, 1994). Self-authorship aligns with the application of the theory of effectuation, which starts with asking: Who I am? Whom do I know? What can I do? The transition from depending on authority figures to determine what you believe, how to view yourself, and how to act in relationships to selfauthorship requires questioning the status quo, exploring multiple perspectives, and constructing one's own beliefs, values, and vision. Students are challenged throughout the course to ask and reflect: What is the role of business in society? What will be their own role in business and society? What are business practices, respectful of responsible management and sustainability? Students explore these questions and define their own answers through self-examination, reflection, listening to others' perspectives, deep engagement, informed dialogue, and critical inquiry. Next, we discuss our pedagogy.

\section{Pedagogy}

Aligned with critical theory, the pedagogical design of the course fosters dialogue and debate as students apply and question the theories they learn. Critical theory has been acknowledged by management educators (see Prasad and Caproni, 1997 and accompanying articles of the special edition in Journal of Management Education) as a tool for changing paradigms and exploring the full potential of management and organizations to create positive change. Aligned with Kearins and Springett (2003), we embrace the following three key concepts of critical theory: reflexivity —reflecting on the assumptions that we make in producing knowledge; critique - exploring how knowledge is constructed and influenced by power and ideology; and social action/engagement - applying, realizing, and practicing ideas to imagine possibilities, new social contracts and relationships between organizations, 
stakeholders, society, and the planet. Both the teaching methods and materials were designed to enable the student to suspend judgement, practice informed reflection, trust the process of learning, and be comfortable that there are multiple pathways for businesses to be change agents.

We were informed by constructionist and critical theory strategies, which resulted in a pedagogy of discovery-problem-based-learning (Fosnot, 2005) and a student-centered classroom where students and faculty interact on an equal plane (Giroux, 1997; Viswanathan, 2012). In addition, we embraced Whitehead's (1929) theory of learning as an active process — a rhythmic iterative cycle of continuously integrating new elements into pre-existing structures. (Allan, 2012; Evans, 1998; Oliver \& Gersham, 1989). Framing learning as an active iterative process is consistent throughout the extant literature in the fields of social entrepreneurship, collaborative innovation, entrepreneurial thinking and action, self-authorship, as well as the best practices of instructional design (Mager, 1997; Reigeluth \& Carr-Chelman, 2009). Therefore, learning activities were developed and continually refined to foster the "process of changing the behavior patterns ... [of the students] ... using behavior in the broad sense to include thinking and feeling as well as overt action” (Tyler, 1949, pp. 5-6). Energy and excitement on the part of both learners (students) and educator are required as class time is spent in high-impact practices: challenge-discussions, informal and impromptu debates, presentations, collaborative problem explorations, and ideation of solutions. Students learn here and now (Whitehead, 1929) by freely thinking, applying knowledge, and testing rightly and wrongly their assumptions.

For in-class sessions, faculty use the structure of Knowledge - Attitude - Behavior, translated to: "What we know affects what we think, and what we think affects what we can do." Students complete self-explorations in each module that are designed to heighten independent learning skills, written expression, and build skills in expressing informed opinions. Students draw upon their selfguided content explorations to have small group discussions and report out on both their personally 
developed insights and the constructed knowledge from the small group process. The classroom is a setting for conversational-experimental exchanges of ideas, allowing students to unfold their perspectives, and imagine possibilities. Conversational learning fosters discussions that are the exchange of ideas, circular in form, and cooperative in manner, enabling students to talk, listen, and learn about values, morals, beliefs, integrity and other ethical issues (Baker, Jensen, \& Kolb, 2002; Brookfield \& Preskill, 1999; Sims, 2004). These pedagogical lenses informed the design of our foundational course.

\section{Introduction to Socially Conscious Business - Let's Be Changemakers}

Rethinking business as a force for good required identifying content materials and resources, creating what we could not find, and knitting it together to develop the foundational course, BUS 101Business, Innovation, \& Entrepreneurial Thinking. The course examines the role of business in society as a force for positive change when practiced responsibly while also focusing on the interdependency of entrepreneurial thinking and innovation with venture creation and business management. To develop entrepreneurial mindsets, we teach alternative ways of thinking and doing including causal reasoning, effectual reasoning, bricolage (Fisher, 2012), and design thinking. We begin the course with an emphasis on managerial thinking — causal reasoning — and end with a focus on entrepreneurial thinking and action - effectuation reasoning. See Figure 2 for a visual roadmap of the course.

Insert Figure 2

The first step in the course is redefining business as responsible through the integration of the three pillars of sustainability, practicing ethical behavior, and global citizenship. Secondly, the students learn the basic foundation of business decision making by utilizing a simulation game. Once students have a foundational frame through which to view business with the 21 st century lens of sustainability and a 
baseline of managerial practice, we move to equipping students with the entrepreneurial mindsets and methods for collaborative innovation. In the last portion of the class, we focus on enabling students to move ideas from whiteboard to launch by applying the theory of effectuation. Interwoven through the four content areas is 'Discovery U,' a set of personal explorations and reflections enabling the student to gain insights into new ways of understanding and valuing themselves and others. Next, we briefly discuss our four content themes.

\section{Causal Reasoning-Managerial Thinking}

Managerial thinking embraces a causal logic inherent in the typical business planning process. In the causal paradigm, we establish objectives to achieve predetermined goals and analyze problems, synthesizing across multiple inputs that rely heavily on data analysis to reduce uncertainty. This approach is helpful to managers whose jobs are to monitor and adjust, or to entrepreneurs who have successfully scaled the venture start-up and entered a more managerial phase of operating. First we familiarize students with how businesses can and do have a positive impact on the world. Next we examine breaches in ethical business practice and then explore the art and the science of doing business through the frameworks of causal reasoning and the pillars of socially conscious business.

\section{Redefine Business as a Force for Good-Responsible Business Management}

The course opens by addressing the changing role of business in society, principles of responsible business management, and the emergence of social entrepreneurship with its new business models. See Table 1 for an overview of module 1, and see the appendix for specific course materials utilized.

\section{Insert Table 1}

First, we use the United Nations Global Compact (UNGC, 2004) to introduce discussions of: What is business's role in society? How have the expectations for business changed? What are examples of issues relating to the implementation of UNGC policy in developing nations? This policy framework is 
paired with the three pillars of sustainability (Savitz, 2014) to operationalize the goals of UNGC, as well as to form the basis of sustainability scoreboards for companies to set goals and measure impacts.

Second, the students investigate the case of the board of directors of The Hershey Company colluding to sell the chocolate manufacturing company without employee or community knowledge or input, by analyzing it from the viewpoint of all stakeholders. They are asked how the lens of sustainability might have affected the actions and outcomes. The case illustrates the loss of value that occurs when management uses maximizing shareholder wealth as its only operating philosophy; the implications of short term, bottom-line thinking; and the consequences of failing to include representatives of all stakeholders in decisions. The unit concludes with the philosophy of social entrepreneurship and an exploration of business models in a variety of legal forms (for-profit, nonprofit and b-corporation).

\section{Develop Business Knowledge through Practice-Management Decisions}

After gaining a deeper insight of what business is, and what it can be, students next develop a deeper understanding of the functional areas of business. Our second content area explores these functional areas and the three pillars of sustainability through the lens of causal logic, which includes: developing the vocabulary and interdependencies of these functional areas of business management; data driven analysis; responsibilities, processes and pressures in making key decisions; sustainability thinking and potential for corrupt practices; problem solving; and teamwork. See Table 1 for an overview of module 2 and see Appendix for specific content utilized.

\section{Insert Table 2}

To accomplish these learning outcomes, we use discovery and problem-based learning methodologies afforded by the online simulation from Marketplace Live's (MPL) Introduction to 
Business and Strategy simulation game (Cadette, 2008). The combination of self-guided explorations and active participation in the simulation challenges students to use reflective practice and collaboration, and develop written and oral communication skills and quantitative literacy. Students practice causal reasoning by strategic planning and utilizing data driven models of decision-making. They review market and internal financial data generated from the real-time competitive market place of competing against the other teams in the class. Teams make decisions on marketing, distribution, human resources, manufacturing, finance, and accounting. Built into the MPL system are content that includes online readings, lectures and stories to both engage and explain the material. Management decisions are embedded in the simulation that make students 'play' and learn business concepts.

To heighten our mission of business not as usual, we modify the MPL simulation to teach the business mindset of integrative thinking; no action occurs in isolation but, rather, has impact inside and outside the organization. First, we integrate selected readings on servant leadership to adapt the: “traditional power-oriented 'leader-first' paradigms that extol a Darwinism and capitalist approach...to building 'people first' organizations that emphasize service to others and recognize that the role of organizations is to create people who can build a better tomorrow" (Parris \& Welty Peachey, 2013b, p. 487). Servant leadership aligns with both responsible management and social entrepreneurship paradigms (Johnson, 2003; Mycoskie, 2011; Parris \& Welty Peachey, 2013a, 2013b; Snell, Chan, Ma, \& Chan 2014). Secondly, our modifications move students beyond a task orientation to experience taking responsibility for their actions, and then reflect on what it means to be socially conscious practitioners. For example, students hire salespeople. We conduct a role-play exercise where students name and develop life-stories for each salesperson. Then when the decisions they make result in poor company performance, they must lay off employees who have names and lives.

Our last modification requires students to maintain a learning log and write a personal reflection for each of the six simulation decision rounds. This process develops a reflective practice as 
to what is working, what is not, what should change. Students summarize new business vocabulary and content that they have learned to enhance retention of new knowledge. Questions about sustainability and the potential for corrupt practices are embedded in learning logs.

We use the simulation as an opportunity for teaching teamwork verses group work. We shape students' expectations for True Teamwork (McInnis-Bowers \& Chew, 2008). Students submit selfreflective and team evaluations at the conclusion of each decision round, reinforcing the criteria for effective teamwork. Introducing students to teamwork skills and allowing time for practice lay the foundation for the less structured collaborative innovation unit that follows.

Departing from the recommended grading and evaluation schema of winners and losers based on earnings, we emphasize the goal for the introductory course as demonstrating responsible management — reflecting on and understanding the consequences of decisions they make, good and bad. Developing the mindsets and skillsets of managerial thinking through doing business is the first building block of the course.

\section{Effectual Reasoning-Entrepreneurial Thinking}

Intrapreneurial and entrepreneurial thinking and action rely on effectual logic, rather than the causal logic of management. Entrepreneurs use effectual reasoning when they are tinkering with an idea, seeking feedback, and developing it over time. Modification in one's thinking, behavior, and business concept is a result of formative and descriptive feedback (Michaelsen \& Schultheiss, 1989; Shute, 2008). Feedback answers three questions: "Where am I going? How am I going? Where to next?" (Hattie and Timperley, 2007, p. 87). As the business concept becomes formalized entrepreneurs shift to causal reasoning when a business plan, management decisions, and stepwise processes are required. Effectual logic is a critical toolset in the process of value creation. 


\section{Engage in Entrepreneurial Mindsets and Processes-Collaborative Innovation}

Our third content area introduces effectual reasoning by integrating the following: listening and servant leadership; empathy and co-creation of value; belief in personal creativity as the path to innovation; and design thinking as problem solving. We integrate concepts from the theories and curriculum of the Transformative Action Institute (TAI, 2013), theory of effectuation (Sarasvathy, 2001; Society for Effectual Action, 2012), Human Centered Design Thinking (IDEO, 2014), and Theory U (Scharmer, 2009) into a cohesive whole for the student. See Table 1 for an overview of module 3 and see the appendix for specific readings and videos used.

\section{Insert Table 3}

We embrace the argument that each person is uniquely creative and innovates daily by adapting to challenges. To foster creativity and build a community of servant leaders, we focus on helping students gain a deeper-level of self-awareness, by developing broader identities and self-efficacy; the ability to see they can make a difference; and emotional awareness - awareness of the healing power of service (Parris \& Welty Peachey, 2013b). Bridging the gap from students' self-authorship of creativity to confident collaboration and openness to new ideas without judgment are pivotal in developing "changemaker" mindsets and skillsets. Bandura (1994) emphasizes that social reformers require a resilient sense of efficacy and a strong belief that they can mobilize a collective effort to bring about social change and innovation. Perceived self-efficacy is one's belief in their capabilities to produce given attainments (Bandura, 1997). Change makers require a resilient sense of efficacy and a strong belief they can mobilize a collective effort to bring about social change. Students explore their sense of personal creativity by participating in in-class exercises to develop convergent and divergent thinking skills. Students also engage in a series of improvisational-theater inspired activities to build skills in 
listening, rapid ideation without self- or peer-imposed judgments, and collaborative creativity through storytelling.

Adding to the novelty of the course design is the partnership with an innovation lab. Working with the innovation lab, the faculty have been trained in HCDT and all students in all course sections go to the innovation lab for a five-hour "Innovation Impact Immersion" experience each term—a design thinking training session resulting in a Human Centered Design Thinking Certificate. A unique aspect of the innovation lab is their philosophy that deep listening, as described by Scharmer's Theory U, forms the foundation for collaborative innovation (Tilstra, 2012). Scharmer's (2009) deep listening requires one to intentionally focus on listening to oneself, to others, and to what emerges from the collective that one convenes. It means to stop and immerse oneself in place and to attend (i.e., listen) to everything one observes, what emerges, and pay particular attention to one's role and journey in the interaction. The faculty integrated content to develop experiential learning activities to capture this philosophy. For example, an empathy safari gets students out of the building to conduct customer discovery interviews (i.e., primary research) on a design challenge question (e.g., How can waste be a resource to make a profit?). Students use deep listening and ideation techniques — 'Yes...And'while suspending judgment rather than evaluating ideas as they emerge (Tilstra, 2012).

As of Spring 2016 more than a thousand students have earned a design thinking certificate. This shared experience builds a sense of community and fosters a culture that embraces each person's ability to make positive change, to be creative, to bring innovation to fruition, and to be open to pivots and different paths forward. We are fortunate to partner with an innovation lab. If this resource is not available faculty can teach HCDT by utilizing the innovation challenge provided by IDEO (https://dschool.stanford.edu/groups/designresources/wiki/ed894/The_GiftGiving_Project.html). Next, we focus on applying the principles of effectuation. 


\section{Identify and Create Opportunities-Application of Effectuation}

Entrepreneurial thinking and action is taught through the lens of effectual logic, which is how expert serial entrepreneurs think and act (Sarasvathy, 2001). See Table 4 for an overview of the module and see the appendix to review course materials used to guide the students through the process of learning and applying this logic. We find the confluence of the theories associated with innovation, design thinking, and particularly, self-efficacy embodied in the thinking and actions of expert serial entrepreneurs and intrapreneurs.

Insert Table 4

Effectuation is a foundational mindset and skillset that consists of the five principles, discussed previously. Students embrace the intuitive simplicity of this schema and find it liberating as they think of the possibilities in what they have, rather than boundaries and constraints of what they lack. Effectuation is key to developing socially conscious practitioners who must practice self-authorship.

\section{Discovery $U$-Self-Authorship}

Discovery $\mathrm{U}$ is integrated across all content areas and uses self-explorations designed to heighten selfawareness and self-reflection, leading to self-authorship — the authentic assertion of self-perspectives and an internalized moral compass (Hodge, Baxer, \& Haynes, 2009). See Table 5 for an overview of learning module, as well as, see appendix for specific materials utilized.

Insert Table 5

Higher education emphasizes the value and process of self-discovery, leading to self-authorship, the authentic assertion of self-perspectives and an internalized moral compass. What makes a socially conscious entrepreneur is an individual's deeply examined sense of self. In this module students 
complete self-guided explorations on: Personal Learning Styles; Personal Temperament; Emotional Intelligence, Locus of Control, Entrepreneurial Aptitude, Servant Leadership; and Life is not a Resume-Happiness. The exploration of values, motivations, attitudes, and personality attributes in a meaningful context can be both revealing and stimulating for students to see themselves as "changemakers."

\section{Implementation, Impact, and Conclusion}

Next, we share our process of continuous improvement, challenges of success, and student feedback. Innovation in Quality Assurance, Replicability, and Scalability

We embraced the creative iterative process of innovation to assure the quality, replicability, and scalability of the course. BUS 101 was first piloted in Spring 2014 with the official launch in Fall 2014. The course has been taught seven terms, fueling the rapid growth of the business program, and serving students across the campus with many non-business majors electing to take it. The popularity of this course has increased the offerings from three sections, in Spring 2014, to nine in subsequent terms, with average class sizes of twenty-two. Each section is taught by an instructor of record, with 68 sections being taught by business adjuncts, and one to three sections taught by full-time faculty.

As of Spring 2017 the course will be replicated over fifty times. We designed each module with supporting turnkey resources to serve day and evening student course formats (i.e., 1, 2, or 3 class sessions per week). This structure enables new adjuncts and faculty to confidently deliver the content, pedagogy, and achieve the learning goals and objectives consistently in each class section, and across each term. All content modules are supported with a combination of instruction tools-lesson plans and assessments, hands-on activities, assignments and self-guide explorations, and open source resources. The modules and course material are on an eLearning platform (i.e., Blackboard) for both faculty and students. To ensure standards and expectations for the course are being reached (i.e., quality assurance) a faculty coordinator is responsible for: incorporating iterative updates; recruiting 
and training adjuncts; conducting teaching method workshops; and coordinating guest speakers and special events for all sections, including the human centered design thinking workshop at the innovation lab. Events both formal and informal, create social spaces to foster a sense of community (Parris \& Welty Peachey, 2013b). Thus, the delivery model has resulted in a sense of unity across nine sections, a sense of teaching community, and a shared experience for more than of 200 students each semester, all seeking to be change makers.

Our empathy for students' needs and life aspirations coupled with the changing societal expectations for businesses, gave us confidence in the viability of our course. We anticipated strong student interest; however, the popularity of the course was staggering. As a result of its popularity, even though the introductory business course had traditionally been a general service course designed to make business education accessible to non-majors, we had to lower the enrollment caps and permitted only majors/minors/freshmen/sophomores to register.

\section{Student Feedback}

The most compelling result is the students' reception to the content and processes taught in our foundational course. They report that their business education is more relevant, connects to their personal aspirations, and is challenging them to do well by doing good. From two representative student quotes, the impact is evident:

Instead of profits, the responsible management and social entrepreneurship focus on helping the planet and the people so that lives may become better for everyone whether it is through running a company in a more ethical manner and donating or creating a hybrid or non-profit entity that is focused on helping others. With responsible management and from what I have heard from my friends, we feel as if we are going to change the world in numerous ways that will not only increase the quality of our lives, but the lives of people across the world. 
I believe that after the first 5 weeks, we had already surpassed what is normally taught in a BUS 101 class at other universities. We learned about who is a successful business leader, how to apply effectuation to create opportunities, among many other things. This course has helped build my creative confidence in the sense of I now have the knowledge and tools I need in to become an ethical entrepreneur.

Reflective essays completed by students express this sentiment and illustrate an empowered intentionality to rethink business as a force for good. See Table 6 for representative student quotes. In addition to self-reported impact, six new ventures have been started by students in the course with business models designed to make a profit while making a social impact.

Insert Table 6

To date, $20 \%$ of our undergraduate student body has completed BUS101 and earned a certificate in design thinking. This shared experience builds a sense of community and fosters a culture that embraces each person's ability to make positive change, to be creative, to bring innovation to fruition, and to be open to pivots and different paths forward.

\section{Conclusion-As an Educator Be a Catalyst for Change}

Our objective was to shape the mindsets and skillsets of the next generation of socially conscious practitioners. We embraced the opportunity to reinvent our introductory business course, and made the following innovations:

- Changed the traditional content of an introduction business course to reflect generational values of current business students; sustainability expectations for successful businesses; critique of business education; and the emergence of social entrepreneurship. 
- Designed four content themes to emphasize sustainability thinking and the application of the triple bottom line as a management philosophy and tool; social entrepreneurship reframing business as a force for good; collaborative innovation \& team skills; and effectuation to imagine possibilities.

- Partnered with an innovation lab for professional level training in HCDT.

- Changed the pedagogy to assure quality outcomes and replicability by organizing content in modules supported by self-guided content explorations with assessments and active learning strategies in face-to-face class sessions.

- Changed the pedagogy using a tech+faculty team combination. The use of an eLearning platform (i.e., Blackboard) for course management enables replicating the course across multiple sections and provides a means for faculty communication and coordination of assignments. The faculty team approach allows for a community of adjuncts and full time faculty to focus intentionally of curriculum assessment and revisions.

This foundational course shapes the students' expectations for how business can be a positive change agent. Societal expectations for sustainable business practices, responsible business management, and social entrepreneurship require business educators to take a leadership role by encouraging and enabling students to create positive impact on the planet and society. Millennials have come of age and have repurposed business. They seek to transform what may have been just a job in years past into a transformative, high impact career. Business education must respond in ways that connect theory to the increasing expectations for sustainability. We applaud the educators who have taken this leap and challenge others to start, so that together we can educate our students be socially conscious business leaders of tomorrow. 


\section{References}

Allan, G. (2012). Modes of learning: Whitehead's metaphysics and the stages of education. SUNY Press.

Ashoka U. (2013). The Exchange, Providence, Rhode Island.

Aspen Institute Center for Business Education. (2009). Aspen's global 100: Beyond grey pinstripes 2009-2010. Retrieved from http:/www.aspeninstritute.org/publications/aspensglobal100

Baker, A. C., Jensen, P. J., \& Kolb, D. A. (2002). Conversational learning: An experiential approach to knowledge creation. Greenwood Publishing Group.

Baker, T., \& Nelson, R. E. (2005). Creating something from nothing: Resource construction through entrepreneurial bricolage. Administrative Science Quarterly, 50(3): 329-366.

Ballou, B., Heiger, D.L., \& Landes, C.E. (2006). The future of corporate sustainability reporting. Journal of Accountancy, 202(6): 65-74.

Bandura, A. (1994). Self-efficacy. In V. S. Ramachaudran (Ed.), Encyclopedia of human behavior (Vol. 4, pp. 71-81). New York: Academic Press. (Reprinted in H. Friedman [Ed.], Encyclopedia of mental health. San Diego: Academic Press, 1998.

Bandura, A. (1997). Self-efficacy: The exercise of control. New York: W.H. Freeman and Company.

Banks, J. A. (1972). The sociology of social movements. London: MacMillan.

Bass, B. M. (1990). From transactional to transformational leadership: Learning to share the vision. Organizational Dynamics, 18(3), 19-31.

Baxter Magolda, M. B. (2001). Making their own way: Narratives for transforming higher education to promote self-development. Sterling, VA: Stylus Publishing.

Benn, S., \& Dunphy, D. (2009). Action research as an approach to integrating sustainability into MBA programs. Journal of Management Education, 33: 276-295. 
Benson, J., \& Dresdow, S. (2013). Design thinking: A fresh approach for transformative assessment practice. Journal of Management Education, 38(3): 436-461.

Bergman, J. Z., Westerman, J. W., Bergman, S. M., Westerman, J., \& Daly, J. P. (2013). Narcissism, materialism, and environmental ethics in business students. Journal of Management Education, 38(4), 489-510.

Blank, S. (2013). The four steps to the epiphany. K\&S Ranch.

Bradfield, S.L. (2009). The value of sustainability education. Journal of Management Education, 33, $372-375$.

Brookfield, S. D., \& Preskill, S. (1999). Discussion as a way of teaching (Vol. 85). San Francisco: Jossey-Bass.

Brown, T. (2008). Design thinking. Harvard Business Review, 86(6): 84.

Brown, T. (2009). Change by design: How design thinking transforms organizations and inspires innovation. New York, NY: Harper. Collins.

Brundtland Commission. (1987). World commission on environment and development. Our common future.

Byrne, J. (2010). Social Entrepreneurship: The best schools and programs. Retrieved from http://poetsandquants.com/2010/08/13/social-entrepreneurship-the-best-schools-programs/6/

Cadette, E.R. (2008). MarketPlace Live, Introduction to business and strategy, Innovative Learning Solutions. Retrieved from http://www.marketplace-simulation.com/introduction-to-business-and-strategy

Crossan, M., Mazutis, D., Seijts, G., \& Gandz, J. (2013). Developing leadership character in business programs. Academy of Management Learning \& Education, 12(2): 285-305.

das Neves, J. C., and Vaccaro, A. (2013). Corporate transparency: A perspective from Thomas Aquinas' summa theologiae. Journal of Business Ethics, 1-10. 
Di Domenico, M., Haugh, H., \&Trace, P. (2010). Social bricolage: theorizing social value creation in social enterprises, Entrepreneurship Theory \& Practice, July: 681-703.

Doorey, D. J. (2011). The transparent supply chain: From resistance to implementation at Nike and Levi-Strauss. Journal of Business Ethics, 103(4): 587-603.

D.school (Stanford University Institute of Design). (2013). Bootcamp bootleg. Retrieved from http://dschool.stanford.edu/wp-content/uploads/2013/10/METHODCARDS-v3-slim.pdf

Eisler, R. (2007). The real wealth of nations: Creating a caring economics. San Francisco, CA: Berrett Koehler.

Elkington, J. (1998). Cannibals with forks: The triple bottom line of $21^{\text {st }}$ century. Gabriola Island, British Columbia, Canada: New Society Publishers.

Engster, D. (2007). The heart of justice: Care ethics and political theory. New York: Oxford University Press.

Evans, M.D. (1998). Whitehead and philosophy of education: The seamless coat of learning. Atlanta, GA: Rodopi.

Fisher, G. (2012). Effectuation, causation, and bricolage: a behavioral comparison of emerging theories in entrepreneurship research. Entrepreneurship Theory and Practice, 36(5): 10191051.

Fosnot, C.(2005). Constructivism: Theory, perspectives, and practice. Teachers College Press.

Frynas, J. G. (2010). Corporate social responsibility and societal governance: Lessons from transparency in the oil and gas sector. Journal of Business Ethics, 93(2): 163-179.

Gartner, W. B., \& Ingram, A. E. (2013). What do entrepreneurs talk about when they talk about failure?. Frontiers of Entrepreneurship Research, 33(6), 2.

Giroux, H.A. (1997). Pedagogy and the politics of hope: Theory, culture, and schooling. Boulder, CO: Westview Press. 
Greenleaf, R. K. (1977). Servant leadership: A journey into the nature of legitimate power and greatness. New York: Paulist Press.

Hattie, J., \& Timperley, H. (2007). The power of feedback. Review of Educational Research, 77(1), 81-112.

Hodge, D. C., Baxer, M., Haynes, C.A. (2009). Engaged learning: Enabling self-authorship and effective practice. Journal of Liberal Education, 94(4): 16-23.

IDEO. (2014). About IDEO. Retrieved from www.ideo.com

Ingols, C., \& Shapiro, M. (2014). Concrete steps for assessing the "soft skills" in an MBA program. Journal of Management Education, 38(3): 412-435.

Johnson, C. (2003). Enron's ethical collapse: Lessons for leadership educators. Journal of Leadership Education, 2(1): 45-57.

Jones, A. L., Warner, B., \& Kiser, P. M. (2010). Social entrepreneurship. Planning for Higher Education, 38(4), 44-51.

Kearins, K., \& Springett, D. (2003). Educating for sustainability: Developing critical skills. Journal of Management Education, 27, 188-204.

Kegan, R. (1994). In over our heads. Cambridge, MA: Harvard University Press.

Kolb, D. (1984). Experiential learning as the science of learning and development. Englewood Cliffs NPH, editor 1984.

Lazarus, H., and McManus, T. (2006). Transparency guru: An interview with Tom McManus. Journal of Management Development, 25(10): 923-936.

Lévi-Strauss, C. (1967). The Savage Mind. Chicago: University of Chicago Press.

Mager, R.F. (1997). Preparing instructional objectives: A critical look in the direction of effective instruction. Atlanta, GA: Center for Effective Performance Press. 
Makary, M. (2012). How to stop hospitals from killing us. Wall Street Journal Eastern Edition, 259(69): C1-C2.

Mair, J., \& Marti, I. (2006). Social entrepreneurship research: A source of explanation, prediction, and delight. Journal of World Bus, 41(1): 36-44.

Martin, R. L., \& Osberg, S. (2007). Social entrepreneurship: The case for definition. Stanford Social Innovation Review, 5(2), 28-39.

McKinsey \& Co. (2010). Pathways to sustainable value creation 2020 http://www.brevolutionconsulting.com/assets/McKinsey-CSR-Strategy.pdf

McKinsey Quarterly. (2014). Profits with purpose: How organizing for sustainability can benefit the bottom Line. McKinsey on Sustainability \& Resource Productivity, July 2014.

McInnis-Bowers, C., \& Chew, E. B. (2008). The true teamwork model: Blending the liberal arts and international business education. Liberal Education, 94(3): 24-29.

Michaelsen, L. K., \& Schultheiss, E. E. (1989). Making feedback helpful. Organizational Behavior Teaching Review, 13(1), 109-113.

Moon, J. A. (2013). Reflection in learning and professional development: Theory and practice. Routledge.

Mycoskie, B. (2011). Start something that matters. Spiegel \& Grau.

Net Impact. (2010). Undergraduate perspectives: The business of changing the world. Retrieved from Www.netimpact.org

Net Impact. (2011). Business skills for a changing world: An assessment of what global companies need from business schools. Retrieved from www.netimpact.org.

Olaison, L., \& Sørensen, B. M. (2014). The abject of entrepreneurship: failure, fiasco, fraud. International Journal of Entrepreneurial Behaviour and Research, 20(2), 193-211. 
Oliver, D.W. \& Gersham, K.W. (1989). Education, modernity, and fractured meaning; Toward a process theory of teaching and learning. Albany, NY: State University of New York Press.

Parris, D., Dapko, J., Arnold, W., \& Arnold, D. (2016). Exploring transparency: A new framework for responsible business management. Management Decision, 54(1), 222-247

Parris, D. L., \& McInnis-Bowers, C. V. (2014). Social entrepreneurship questioning the status quo: Waste as a resource. Journal of Economic Issues, 48(2): 359-366.

Parris, D., \& Welty Peachey, J. (2012). Building a legacy of volunteers through servant leadership: A cause $\square$ related sporting event. Nonprofit Management and Leadership, 23(2), 259-276.

Parris, D. L., \& Welty Peachey, J. W. (2013a). A systematic literature review of servant leadership theory in organizational contexts. Journal of Business Ethics, 113(3): 377-393.

Parris, D. L., \& Welty Peachey, J. W. (2013b). Encouraging servant leadership: A qualitative study of how a cause-related sporting event inspires participants to serve. Leadership, 9(4): 486-512.

Persons, O. (2012). Incorporating corporate social responsibility and sustainability into business course: a shared experience. Journal of Education for Business, 87(2): 63-72.

Pfeffer, J. (2010). Building sustainable organizations: The human factor. Academy of Management Perspectives, 24(1): 34-45.

Prasad, P., \& Caproni, P. J. (1997). Critical theory in the management classroom: Engaging power, ideology, and praxis. Journal of Management Education, 21(3), 284.

PRME (Principles for Responsible Management Education). (2015). Six principles. Retrieved from http://www.unprme.org/

Reigeluth, C. M., \& Carr-Chellman, A.A. (Eds.). (2009). Instructional-design theories and models: Volume III. Building a common knowledge base. New York: Routledge.

Rusinko, C. A. (2010). Integrating sustainability in management and business education: A matrix approach. Academy of Management Learning \& Education, 9(3): 507-519. 
Sarasvathy, S. D. (2001). Causation and effectuation: Toward a theoretical shift from economic inevitability to entrepreneurial contingency. Academy of Management Review, 26(2): 243263.

Savitz, A., \& Weber, K. (2006). The triple bottom line: How today's best-run companies are achieving economic, social and environmental success - and how you can too. Josey-Bass, San Francisco, Ca.

Scharmer, C. O. (2009). Theory U: Learning from the future as it emerges. Berrett-Koehler Publishers.

Sendjaya, S., and Sarros, J. (2002). Servant leadership: Its origin, development, and application in organizations. Journal of Leadership and Organizational Studies, 9(2), 57-64.

Shute, V. J. (2008). Focus on formative feedback. Review of Educational Research, 78(1), 153-189.

Sims, R. R. (2004). Business ethics teaching: Using conversational learning to build an effective classroom learning environment. Journal of Business Ethics, 49(2), 201-211.

Society for Effectual Action. (2012). Effectuation. Retrieved from www.effecuation.org

Snell, R. S., Chan, M. Y. L., Ma, C. H. K., \& Chan, C. K. M. (2014). A road map for empowering undergraduates to practice service leadership through service-learning in teams. Journal of Management Education, 39(3) 372-399.

Sroufe, R., Sivasubramaniam, N., Ramos, D., \& Saiia, D. (2014). Aligning the PRME How Study Abroad Nurtures Responsible Leadership. Journal of Management Education, 39(2): 244-275.=

Starik, M., Rands, G., Marcus, A. A., \& Clark, T. S. (2010). From the guest editors: In search of sustainability in management education. Academy of Management Learning \& Education, 9(3): 377-383.

TAI (Transformative Action Institute). (2013). Social innovation curriculum workshop. 
Tekarslan, E., \& Erden, N. S. (2014). A review of business education around the globe: Future transitions. Journal of Multidisciplinary Research, 6(2): 49-64.

Thomas, H., Lee, M., Thomas, L., \& Wilson, A. (2014). Securing the future of business education: Competitive destruction or constructive innovation? Bingley, UK: Emerald Group Publishing.

Tilstra, K. (2012). Leadership programs designed to develop creative leaders: A multi-case study. Dissertations. Paper 732. http://digitalcommons.andrews.edu/dissertations/732

Tyler, R.W. (1949). Basic Principles of Curriculum and Instruction. University of Chicago Press, London.

UNCG. (2014). United National Guild to Corporate Sustainability. Retrieved from https://www.unglobalcompact.org

Viswanathan, M. (2012). Curricular innovations on sustainability and subsistence marketplaces: philosophical, substantive, and methodological orientations. Journal of Management Education, 36, 389-427.

Welsh, M. A., \& Dehler, G. E. (2013). Combining critical reflection and design thinking to develop integrative learners. Journal of Management Education, 37(6), 771-802.

Werner, F. M., \& Stoner, J.A.F. (2015). Transforming finance and business education: Part of the problem. Journal of Management for Global Sustainability. 3(1): 25-52.

Whitehead, A.N. (1929). The Aims of Education and Other Essays. Free Press, New York.

Wood, M. \& Dibben, M. (2015). Leadership as relational process. Process Studies, 44(1): 24-47. 
Figure 1

Ideation to Launch: Development of a Socially Conscious Introductory Business Course

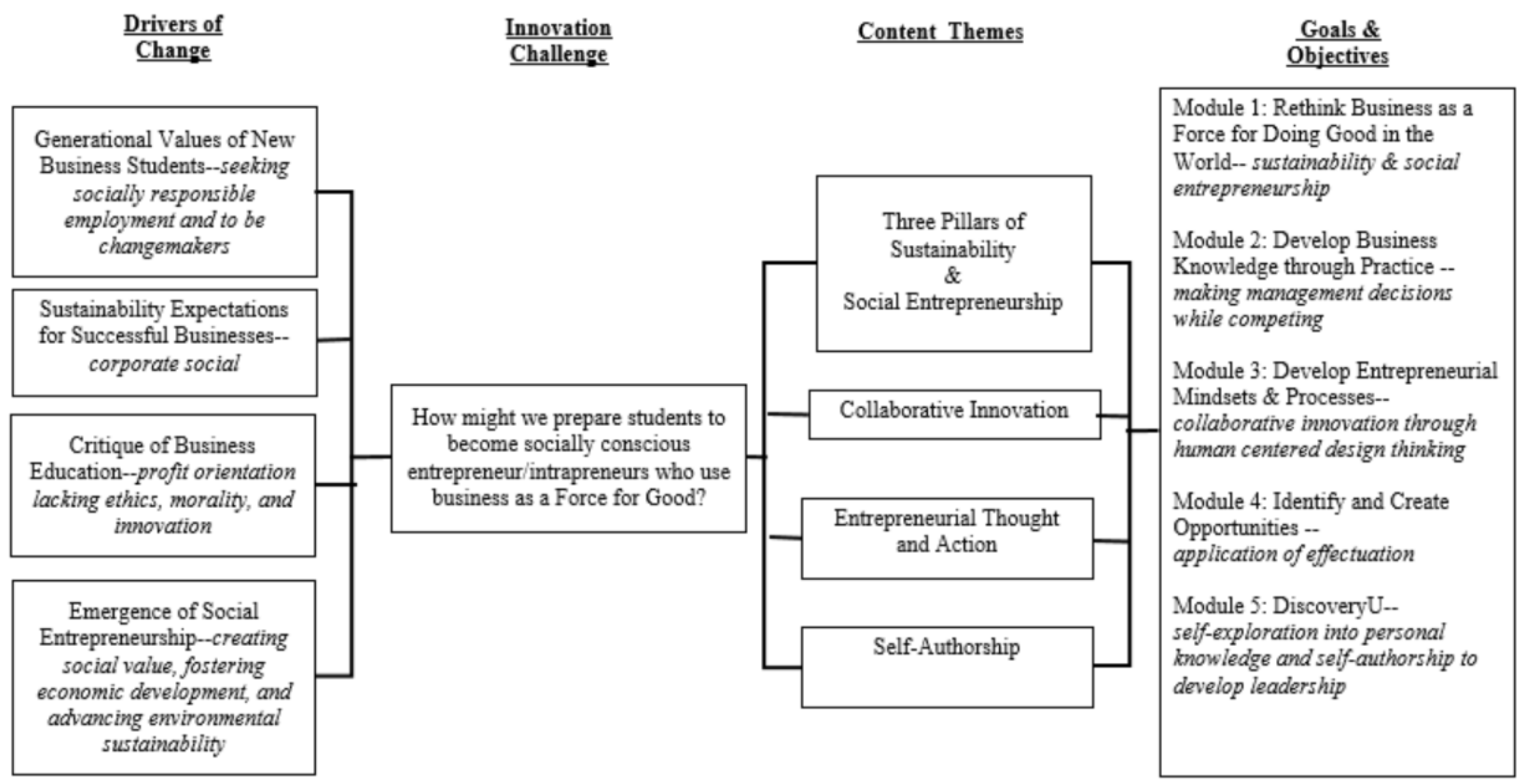




\section{Figure 2}

Causal to Effectual Reasoning in Business Innovation and Entrepreneurial Thinking

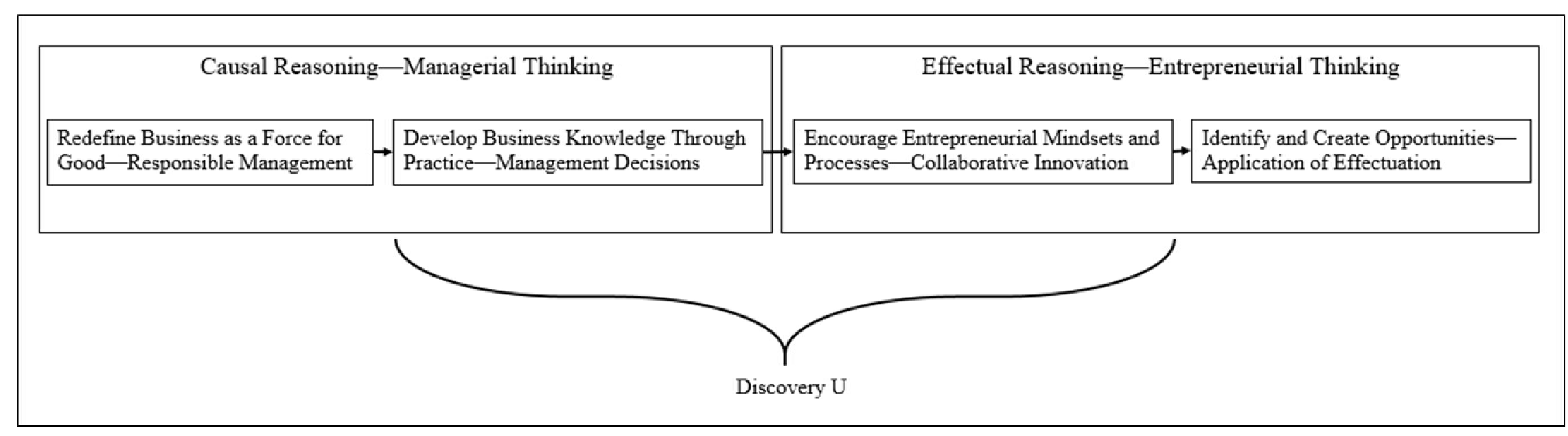


Table 1

Module 1 Overview: Refine Business as a Force for Good

\begin{tabular}{|c|c|c|}
\hline Goals \& Objectives & Content & Pedagogy \\
\hline $\begin{array}{l}\text { 1.1 Examine the changing role of business in } \\
\text { society } \\
\text { 1.2 Explore social entrepreneurship as } \\
\text { rethinking business } \\
\text { 1.3 Learn principles of responsible business: } \\
\text { sustainability; triple bottom line; } \\
\text { economic growth with ethical behavior; } \\
\text { global citizenship; and corporate } \\
\text { responsibility. } \\
\text { 1.4 Understand business-entrepreneurial } \\
\text { mindsets and skillsets as ways of problem } \\
\text { for-profit, nonprofit, hybrid forms } \\
\text { solving - creating and delivering value to } \\
\text { problems }\end{array}$ & $\begin{array}{l}\text { Changing the role of business in } \\
\text { society-UN Global Compact on } \\
\text { Business } \\
\text { - Social entrepreneurship applying } \\
\text { the business mindset and skillset } \\
\text { to solving social problems } \\
\text { Sustainability thinking: how to } \\
\text { create a win-win by moving } \\
\text { beyond corporate social } \\
\text { responsibility } \\
\text { Organizational fit to mission - } \\
\text { Management strategies and tools } \\
\text { for measuring societal impact: } \\
\text { Triple Bottom Line Scoreboards }\end{array}$ & $\begin{array}{l}\text { - Four mixed } \\
\text { media, self- } \\
\text { guided content } \\
\text { explorations } \\
\text { - Student research } \\
\text { presentations on } \\
\text { ethical and } \\
\text { unethical } \\
\text { companies tied } \\
\text { to principles of } \\
\text { the U.N. Global } \\
\text { Compact on } \\
\text { Doing Business } \\
\text { on sustainability }\end{array}$ \\
\hline
\end{tabular}


Table 2

Module 2 Overview: Develop Business Knowledge through Practice

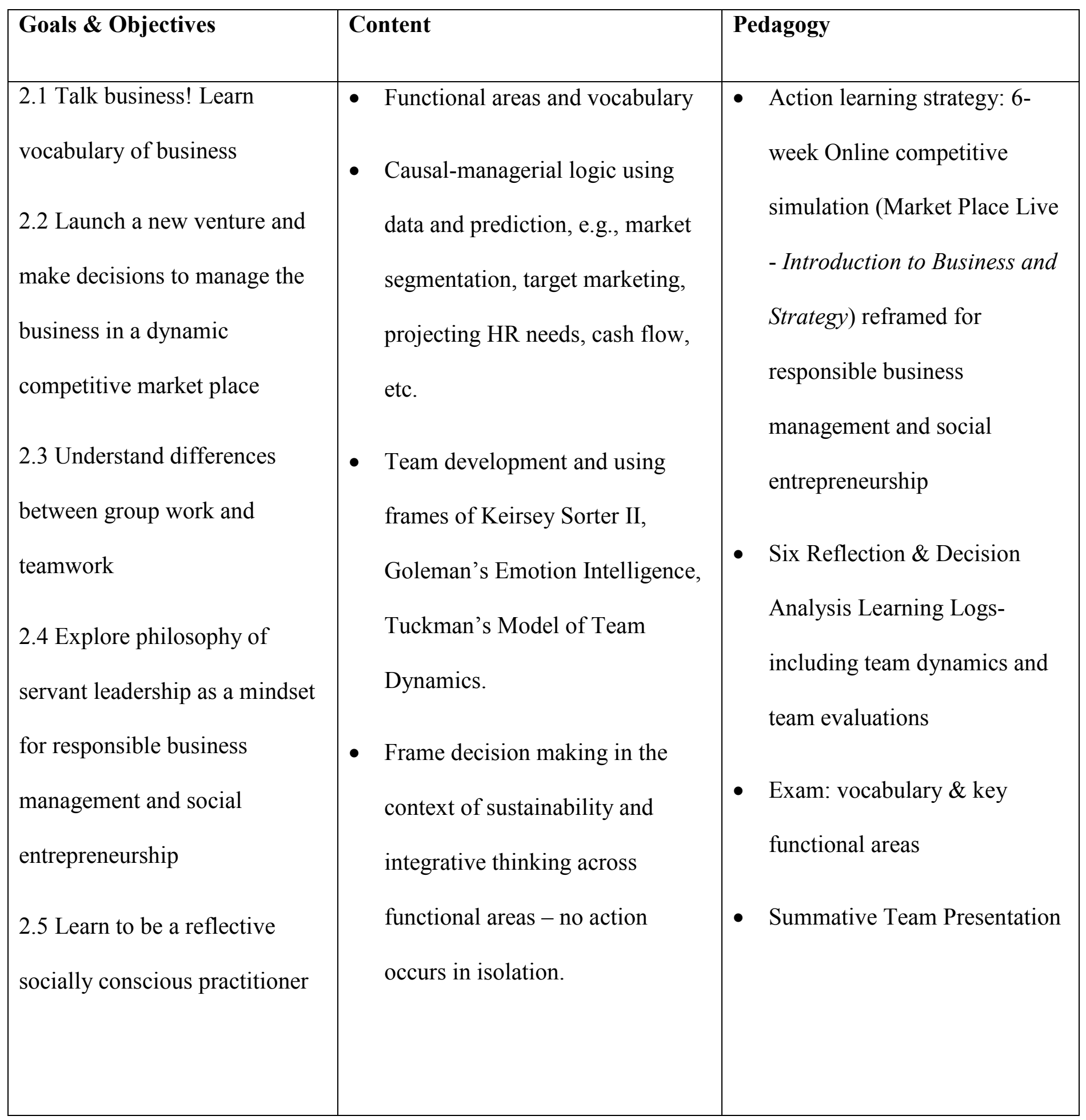


Table 3

Module 3 Overview: Develop Entrepreneurial Mindsets and Processes

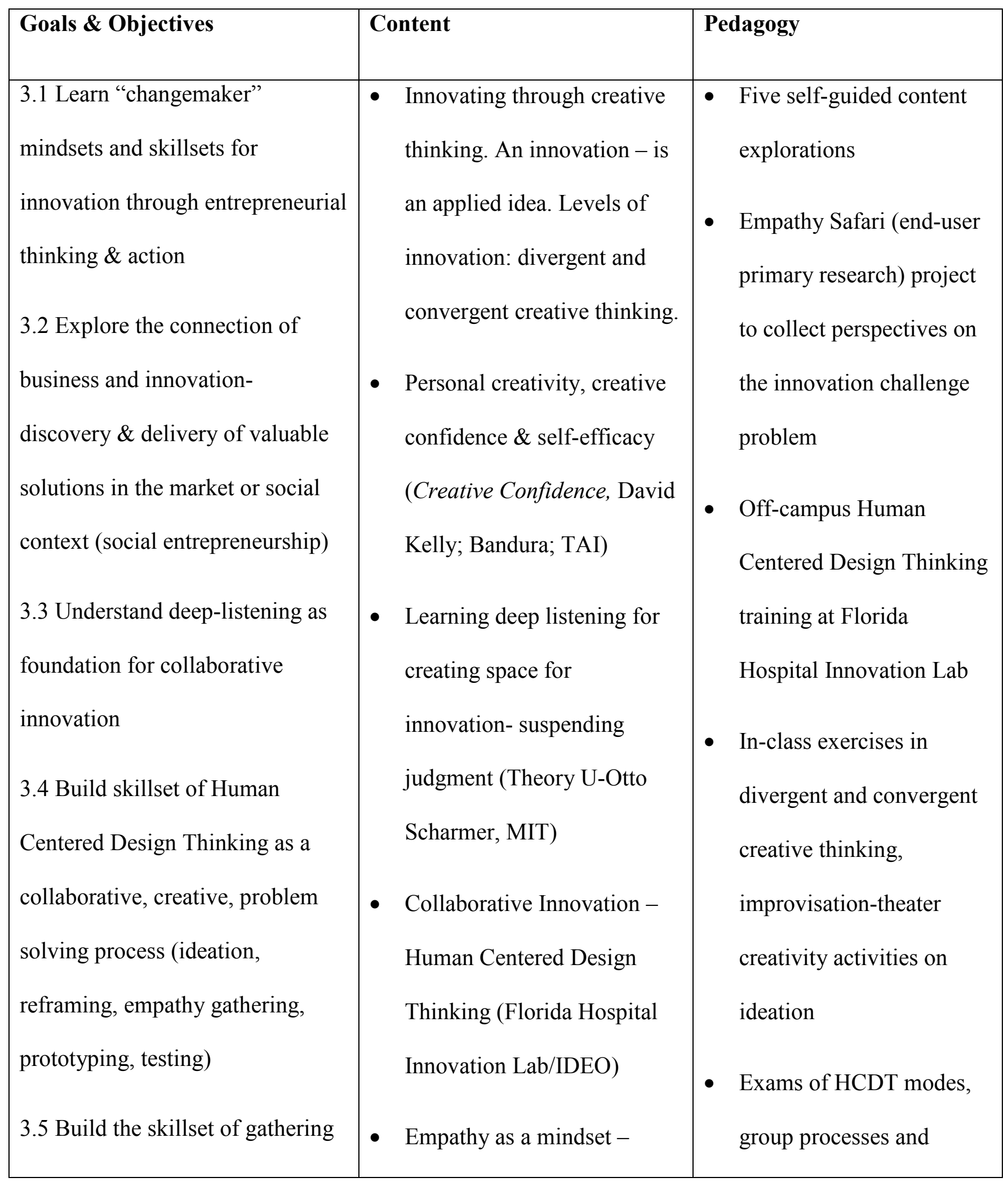


empathy (end-user perspective) and the power of co-creation of value for innovation value diversity, capture

customer pain-pleasure

points vocabulary and final Be

Entrepreneurial - Change

something! Project 
Table 4

Module 4 Overview: Identify and Create Opportunities

\begin{tabular}{|c|c|c|}
\hline Goals \& Objectives & Content & Pedagogy \\
\hline $\begin{array}{l}4.2 \text { Understand that } \\
\text { leading/acting as an } \\
\text { innovator means being a } \\
\text { change-agent both from the } \\
\text { outside (entrepreneurs) and } \\
\text { inside of existing } \\
\text { organizations (intrapreneurs) } \\
4.2 \text { Demystify the myths of } \\
\text { being an entrepreneur } \\
4.3 \text { Creating Opportunities } \\
\text { through the effectuation } \\
\text { process- where do ideas } \\
\text { come from? }\end{array}$ & $\begin{array}{l}\text { Entrepreneurs are not visionaries } \\
\text { - they are us } \\
\text { - Opportunity recognition- } \\
\text { opportunity identification by } \\
\text { starting with your personal } \\
\text { means/resources } \\
\text { Decision-making principles for } \\
\text { optimizing uncertainty with a } \\
\text { bias towards action } \\
\text { Failure is expected and } \\
\text { - } \\
\text { liberating - Failure a source of } \\
\text { of people (customer, } \\
\text { new opportunities }\end{array}$ & $\begin{array}{l}\text { In-class exercises: Mapping } \\
\text { applications of HCDT \& } \\
\text { Effectuation; Personal } \\
\text { Means assessment for Bird- } \\
\text { In-Hand principle; Imagine } \\
\text { \& make an opportunity } \\
\text { starting with your means } \\
\text { (i.e., who you are, what you } \\
\text { can do, and who you know) } \\
\text { Final Exam Presentation: Be } \\
\text { Entrepreneurial! Students } \\
\text { map their applications of } \\
\text { HCDT and Effectuation to } \\
\text { innovate ...to change }\end{array}$ \\
\hline
\end{tabular}


Table 5

Module 5 Overview: Discovery U

\begin{tabular}{|c|c|c|}
\hline Goal \& Objectives & Content & Pedagogy \\
\hline $\begin{array}{l}5.1 \text { Though a process of } \\
\text { self-discovery, identify } \\
\text { and celebrate personal } \\
\text { strengths and } \\
\text { opportunities for } \\
\text { improvement } \\
5.2 \text { Develop attitudes, } \\
\text { competencies and skills } \\
\text { for entrepreneurial and } \\
\text { innovative thinking that } \\
\text { will bring value to all } \\
\text { aspects of your life } \\
\text { change agent } \\
\text { understanding of self as a }\end{array}$ & $\begin{array}{l}\text { - Learning styles and ways to improve } \\
\text { comprehension, retention \& retrieval. } \\
\text { - Emotional Intelligence: strengths and self- } \\
\text { prescription for growth? } \\
\text { - Temperament for decision making? } \\
\text { - Strengths and areas for growth? } \\
\text { - Lelf-Efficacy: Can I effect change? } \\
\text { - Eocus of control and decision-making? } \\
\text { - Thtrepreneurial Aptitude - vocabulary to } \\
\text { describe your entrepreneurial style } \\
\text { and problem solving }\end{array}$ & 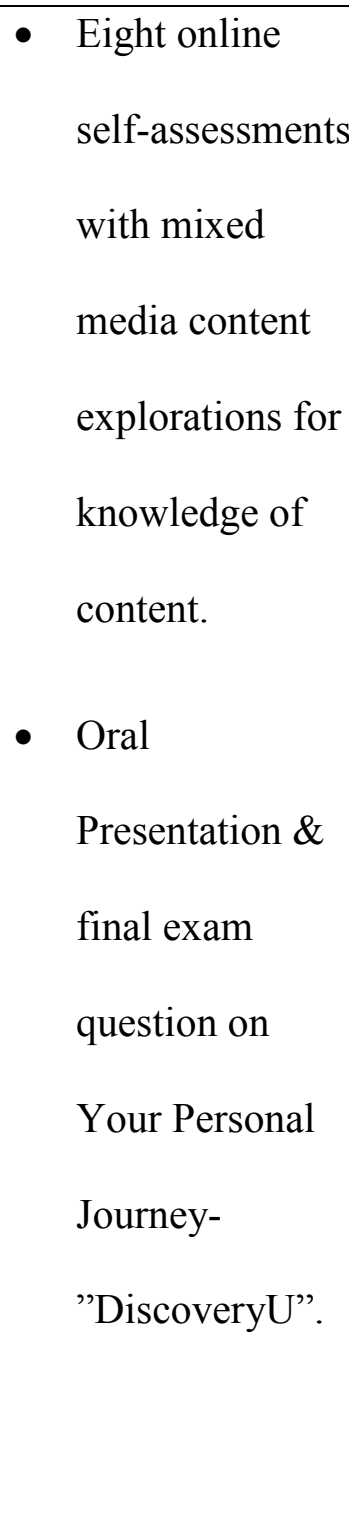 \\
\hline
\end{tabular}


Table 6

Student Quotes Demonstrating Learning Outcomes: A Community of Changemakers

\begin{tabular}{|c|c|}
\hline $\begin{array}{l}\text { as a Force for } \\
\text { Good-Responsible }\end{array}$ & $\begin{array}{l}\text { I realize that people are creating these new ideas and are thinking in a different light than many people did } 5 \text { or } 10 \text { years ago. } \\
\text { Our world is shifting and changing in more ways than one and more people are trying to make a positive impact on our } \\
\text { world. }\end{array}$ \\
\hline \multirow[t]{4}{*}{ Management } & $\begin{array}{l}\text { This course is extremely different then any business course I have taken before. It allows me to think of business with a totally } \\
\text { different perspective. Instead of just thinking of business as a way to make money, I am now starting to think of ways to } \\
\text { generate businesses that can have a positive impact on a community. I believe it makes my education more valuable and up to } \\
\text { date with today's expectations of business students. }\end{array}$ \\
\hline & $\begin{array}{l}\text { If more businesses focused on integrating sustainability into their business plans true social change would occur and business } \\
\text { would be rewarded in the long run, making sustainability not only of moral importance, but also a smart business decision. }\end{array}$ \\
\hline & $\begin{array}{l}\text { I was most surprised that it wasn't a typical business course. I always thought of entrepreneurs as just these money } \\
\text { machines. It didn't seem like something attainable. But now it is, and I've realized that entrepreneurialism is about making } \\
\text { social change and really valuing other people in the process. It's inspiring and has changed my outlook on the impact that } \\
\text { I'm able to make. }\end{array}$ \\
\hline & $\begin{array}{l}\text { Business is such a valuable resource because it impacts everyone, across the nation and worldwide. What better way to } \\
\text { invoke change than to start with something that affects everyone everywhere? I feel as though this course was made for me. I }\end{array}$ \\
\hline
\end{tabular}




\begin{tabular}{|c|c|}
\hline & am driven by my passions, and something that I am very passionate about is making a difference in this world. \\
\hline \multirow{5}{*}{$\begin{array}{l}\text { Develop Business } \\
\text { Knowledge Through }\end{array}$} & I learned a broad range of skills necessary to successfully understand how a company functions though realistic experiences. \\
\hline & $\begin{array}{l}\text { Concentrating only on making money will generate selfish decisions and create issues within the company which gives } \\
\text { companies with good internal relationships an advantage. }\end{array}$ \\
\hline & $\begin{array}{l}\text { The course prepared me to work side-by-side with business leaders to address business, social, and environmental } \\
\text { challenges. It also prepares me to be a responsible business leader, and integrate sustainability into business practices. } \\
\text { Lastly, it trains me to be a source of transformative change in any workplace by studying the primacy of the triple bottom line } \\
\text { (people, planet, profit) in decision making. }\end{array}$ \\
\hline & $\begin{array}{l}\text { The way we are being taught is a more organic approach to business. This class alone we were introduced to the fact that } \\
\text { creating a business does not have to be a linear process consisting only of numbers and profit predictions. }\end{array}$ \\
\hline & $\begin{array}{l}\text { I realized that running a business is not just about profit. It is about satisfying a variety of things such as other people's } \\
\text { needs, the community's needs. The triple bottom line was never something I had taken into account when thinking about how } \\
\text { successful businesses stayed successful and competitive with the changing world. }\end{array}$ \\
\hline $\begin{array}{l}\text { Encourage } \\
\text { Entrepreneurial }\end{array}$ & $\begin{array}{l}\text { Empathy is now my best and most unique skill set. It is when you put yourself in someone else's shoes and come up with } \\
\text { innovative ways to create new business ventures or innovations. }\end{array}$ \\
\hline $\begin{array}{l}\text { Mindsets and } \\
\text { Processes- }\end{array}$ & $\begin{array}{l}\text { BUS } 101 \text { has made me socially conscious and aware of the people around me. It's changed me into someone who's more } \\
\text { empathetic rather than just sympathetic towards people's problems. Positive change created for the people in mind should be }\end{array}$ \\
\hline
\end{tabular}




\begin{tabular}{|c|c|}
\hline \multirow{6}{*}{$\begin{array}{l}\text { Collaborative } \\
\text { Innovation }\end{array}$} & the heart of innovation. \\
\hline & $\begin{array}{l}\text { HCDT helps students like us create better solutions, develop design thinkers, and foster a culture of innovation. I learned to } \\
\text { be a co-creative person, and to collaborate and solve solutions to challenges. }\end{array}$ \\
\hline & I gained .... ways to think as an innovative and design thinker, and create a culture of innovation in my community. \\
\hline & $\begin{array}{l}\text { Having empathy for others and obtaining the ability to collect empathy from others is a value and skill that I learned in the } \\
\text { class. }\end{array}$ \\
\hline & $\begin{array}{l}\text { People from varying backgrounds can create interesting business prototypes that could eventually change behavior....It } \\
\text { really helped me learn every idea could build upon another. }\end{array}$ \\
\hline & $\begin{array}{l}\text { Creativity is a term that I have always associated with art. This class has taught me a new meaning to an old word. I learned } \\
\text { that creativity can also mean the power to solve problems. Most people do this on a daily basis; therefore I have been } \\
\text { "creative" this whole time without my knowledge. I am pleased to say that I now tell others that they are creative when they } \\
\text { say that they don't feel that way. }\end{array}$ \\
\hline $\begin{array}{l}\text { Identify and Create } \\
\text { Opportunities - }\end{array}$ & $\begin{array}{l}\text { By learning the process of effectuation, I was able to use the creative ideas I had, and accurately assess them from the ground } \\
\text { up. I believe this attribute will be extremely helpful in maintaining my business in the future. }\end{array}$ \\
\hline $\begin{array}{l}\text { Application of } \\
\text { Effectuation }\end{array}$ & $\begin{array}{l}\text { Effectual logic is all about operating in an unknown and unpredictable future, seeing a fork in the road and going for it. We } \\
\text { are so held back sometimes because of fear, fear of the unknown. We are so afraid to mess up or to take the wrong path. } \\
\text { Effectuation reminds me that no path is wrong, it is simply the right way to a new place. }\end{array}$ \\
\hline
\end{tabular}




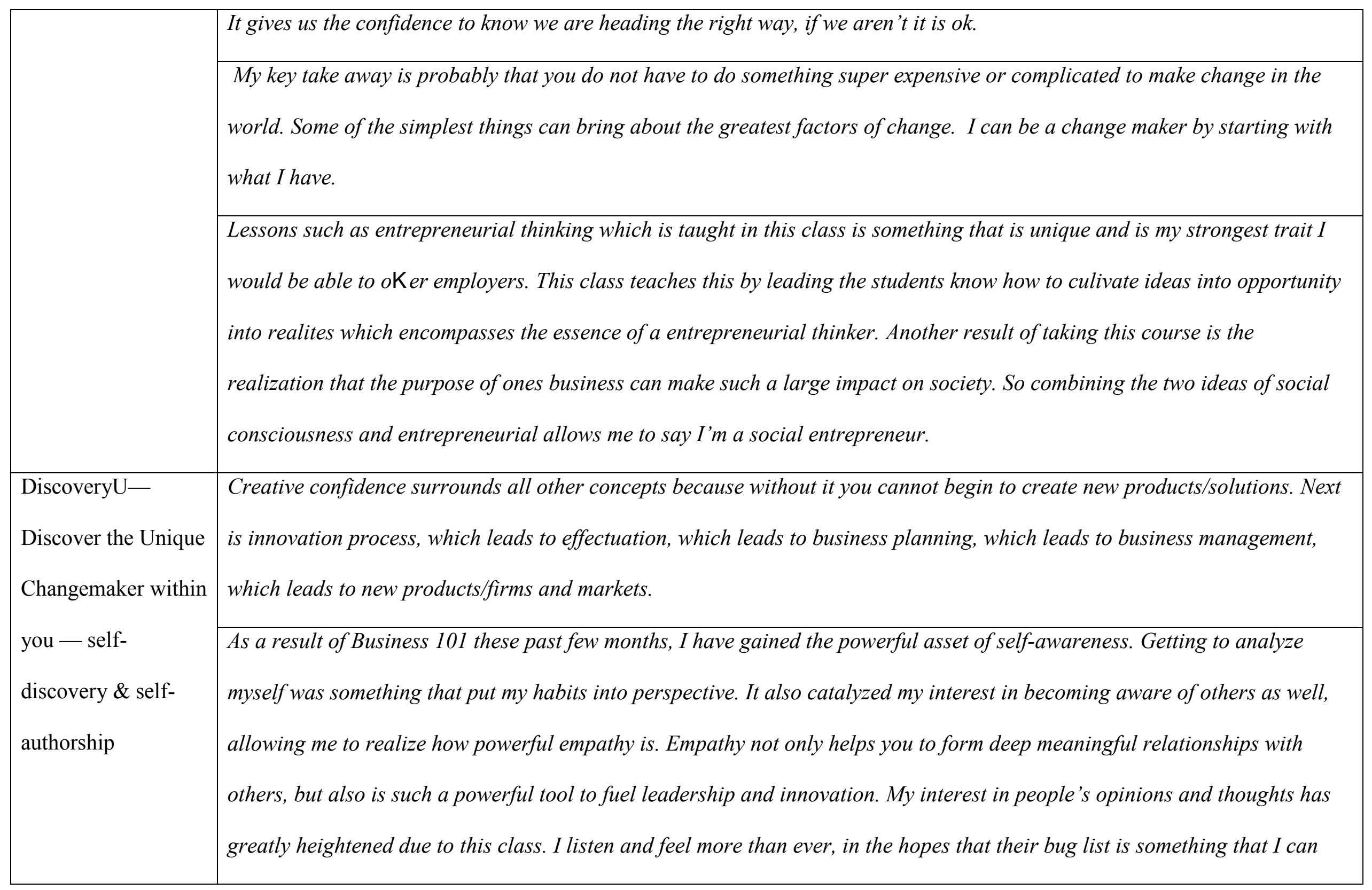




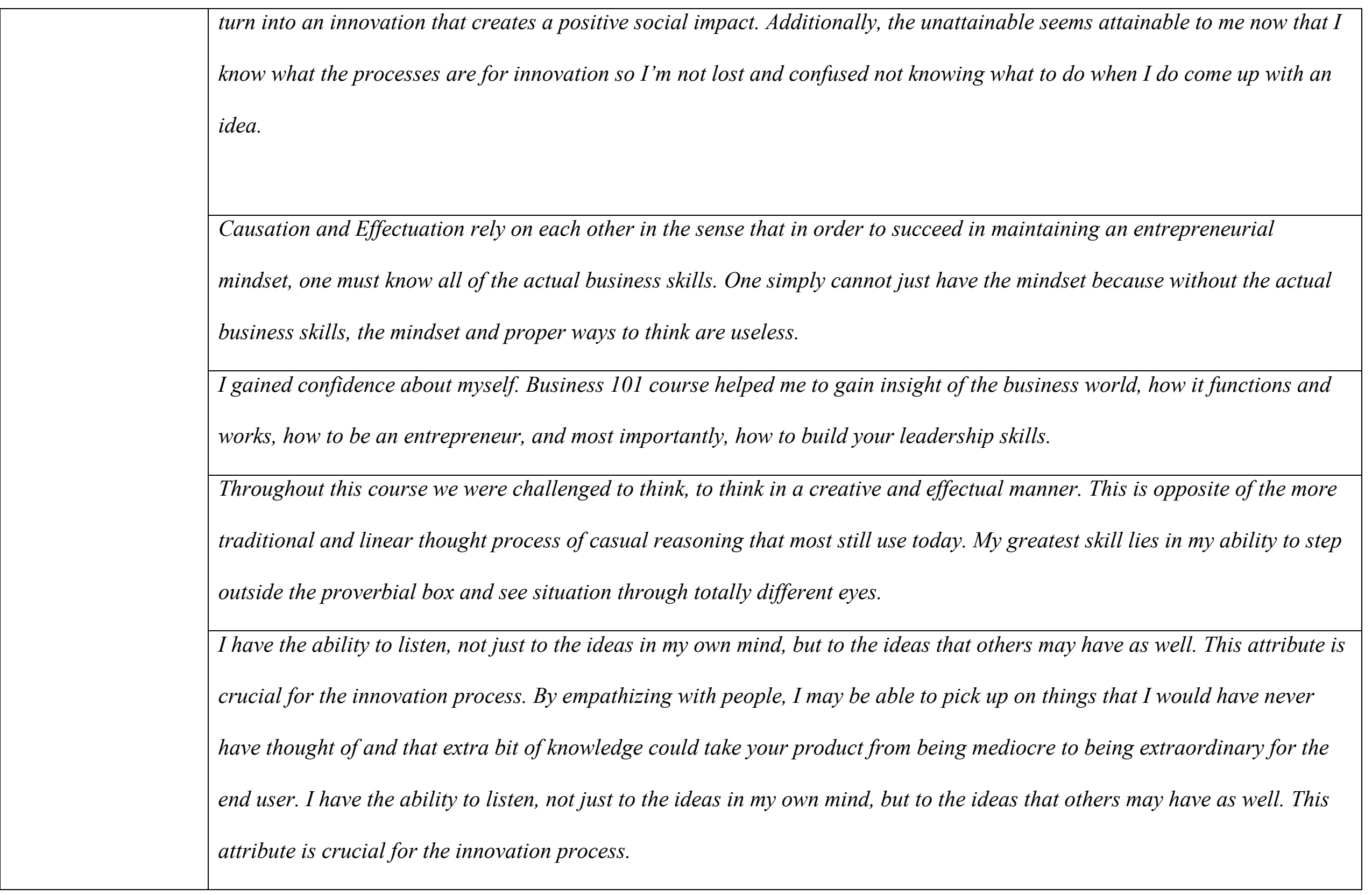




\begin{tabular}{|l|l|}
\hline & $\begin{array}{l}\text { This class prepared me to make a lifelong social impact as a leader and Change Maker because this course focuses on what } \\
\text { really matter in business; the substance that people often miss when thinking methodically about industries. I will learn more } \\
\text { than just how to obtain gross amounts of money and how to procure upward sloping projections for the next fiscal year. } \\
\text { Rather, along with those factors, I will be educated on political, economic, and social issues, which will give me the chance to } \\
\text { think of innovative and sustainable solutions, and because of this course I will day by day learn how to make an impact on } \\
\text { business, and then in turn - the world. }\end{array}$ \\
\hline
\end{tabular}




\section{Appendix}

Content Integrated in Self-Explorations and Class Discussion for Each Learning Module

*Module 5 (Self-Authorship) content is integrated in Modules 1-4 and are indicated by an asterisk.

Module 1: Redefine Business as a Force for Good—Responsible Business Management

- Business Skills for A Changing World

https://netimpact.org/sites/default/files/documents/business-skills-changing-world-2011.pdf

- Ten Principles of the Global Compact https://www.unglobalcompact.org/what-is$\mathrm{gc} / \mathrm{mission} /$ principles

- Guide to Corporate Sustainability Report: Shaping a Sustainable Future https://www.unglobalcompact.org/docs/publications/UN Global Compact Guide to Corporat e Sustainability.pdf

- Video: History of the Global Compact https://www.youtube.com/watch?v=MQLXA1Nhjuo

- Video: Italian commercial explaining the Rationale for the UN Global Compact https://www.youtube.com/watch?v=hBRLRehpVY0

- Video: UN and private sector relationship to solve poverty https://www.youtube.com/watch?v=qK0Z3qeuiAM

- Video: Making global labor fair https://www.ted.com/talks/auret_van_heerden_making_global_labor_fair

- Video: Why focusing on shareholder value is bad for shareholders https://www.youtube.com/watch?v=fMNuDZYiqTY

- What is Corporate Social Responsibility? https://www.youtube.com/watch?v=E0NkGtNU 9w\&feature=youtu.be

- Introduction, chapter 1, 2, \& 3, The Triple Bottom Line, Savitz and Weber, JossyBass, 2006 
- Video: Living the Legacy: The Milton Hershey Story, https://www.youtube.com/watch?v=cGlwqNaq-eo

- Video: What is the business case for sustainability? https://www.youtube.com/watch?v=K1W8WW0k3g

- Video: How does sustainability create value for a business? https://www.youtube.com/watch?v=jpeS91FDHpY

- The corporation as a force for good. Interview with Jeff Weiner, CEO LinkedIn, Inc. https://www.youtube.com/watch?v=H1T4bBhawZo\#t=35

- The Rise of the Social Entrepreneur, New York Times, David Bornstein http://opinionator.blogs.nytimes.com/2012/11/13/the-rise-of-socialentrepreneur/? php $=$ true \& type $=$ blogs\& $\mathrm{r}=01.3$

- 5 Lessons from Skoll on Social Entrepreneurship http://www.forbes.com/sites/johnrampton/2014/04/17/5-lessons-learned-from-skoll-worldforum-on-social-entrepreneurship/

- How do Social Entrepreneurs Revolutionize Industries? https://www.ashoka.org/sites/www.ashoka.org/files/2013-Impact-Study-FINAL-web.pdf

- Selected Social Entrepreneurship and Social Innovation Business Models:

○ Water for Waves http://www.wavesforwater.org/about/story

○ Clean the World https://cleantheworld.org

○ Rebuild Globally http://rebuildglobally.org/rebuild-globally/

○ IDignity http://www.idignity.org/about

○ BE Benevolent http://www.benevolent.net/index.html?view=success 
- Chapter 20, Entrepreneurship as a technology for social change? From Read, S., Sarasvathy, S., Dew, N., Wiltbank, R., \& Ohlsson, A. V. (2010). Effectual entrepreneurship. Taylor \& Francis.

Module 2: Develop Business Knowledge through Practice-Management Decisions

- Introduction to Business Strategy: A Market Place Live Business Simulation http://www.marketplace-simulation.com/introduction-to-business-and-strategy

- *Keirsey's Temperaments https://www.youtube.com/watch? v=j2z67HLV4ls

○ Temperament survey: http://www.keirsey.com/sorter/register.aspx

- *Emotional Intelligence Executive Briefing:

○ https://www.cu.edu/sites/default/files/ExecWorkingEI.pdf

○ http://www.talentsmart.com/about/emotional-intelligence.php

○ http://psychology.about.com/od/emotion/f/what-are-emotions.htm

○ http://psychology.about.com/od/emotion/tp/purpose-of-emotions.htm

- *Video: Emotional Intelligence by Daniel Goleman https://www.youtube.com/watch?v=n6MRsGwyMuQ

- *Video: Emotional Intelligence by Travis Bradberry https://www.youtube.com/watch?v=JziINJBG9Xo

- *Video: Leading with Emotional Intelligence in the Workplace https://www.youtube.com/watch?v=OoLVo3snNA0

Module 3: Engage in Entrepreneurial Mindsets and Processes-Collaborative Innovation

- What is Design Thinking? By Tim Brown, Harvard Business Review https://www.ideo.com/images/uploads/thoughts/IDEO_HBR_Design_Thinking.pdf 
- Video: What is Design Thinking? By Daylight

- $\quad$ http://www.whatisdesignthinking.org/

- Bootcamp Bootleg from the d. School Hasso Plattner Institute of Design at Stanford

- $\quad$ https://dschool.stanford.edu/wp-content/uploads/2011/03/BootcampBootleg20s10v2SLIM.pdf

- *Video: The Essence of Leadership, Otto Scharmer

- $\quad$ https://www.youtube.com/watch?v=8sdIIx6eCbE\&list=PLWP7J8UaSOds04IK1KUjrXJPXINY $\underline{\mathrm{hK} 5 \mathrm{t} \& \text { index }}=1$

- *Theory U Executive Summary

- https://www.presencing.com/sites/default/files/page-files/Theory U Exec Summary.pdf

- *Four levels of listening, Otto Scharmer

- $\quad$ https://www.youtube.com/watch?v=eLfXpRkVZaI

- Video: What is HCDT? By Human Factors Research, https://www.youtube.com/watch?v=a7sEoEvT818

- Video: One week at IDEO-HCDT in 2 Minutes https://www.youtube.com/watch?v=xWmJRFur-SU

- Understanding the five Modes of HCDT (produced or curated by Florida Hospital Innovation Lab- FHIL)

- Video:_Empathy https://www.youtube.com/watch?v=10iJ7P2OtkU

- Video: Reframing by FHIL https://www.youtube.com/watch?v=Ca5Vu8iT6aI

- Video: Ideate by FHIL https://www.youtube.com/watch?v=8dm4iVWyOV0

- Video: Prototype by FHIL https://www.youtube.com/watch?v=FnJIJEUBLms

- Video: Test by FHIL https://www.youtube.com/watch?v=2me7pcteY5A

- Empathy on the Edge, Tim Brown, IDEO 
- https://www.ideo.com/images/uploads/news/pdfs/Empathy on the Edge.pdf

- Ethnography for Empathy, Ellen Isaacs

- $\quad$ https://www.youtube.com/watch?v=nV0jY5VgymI

- Yes, And... for Empathy, Karen Tilstra, Director of the Florida Hospital Innovation Lab

- $\quad$ https://www.youtube.com/watch?v=11SK qNLx5U

Module 4: Identifying and Creating Opportunities - Application of Effectuation

- What makes entrepreneurs entrepreneurial? Sarasvathy, Saras D.

http://www.effectuation.org/sites/default/files/documents/what-makes-entrepreneursentrepreneurial-sarasvathy.pdf

- Video: Think like an innovator. https://www.youtube.com/watch?v=FSxSinVVRLw

- Video: Where do ideas come from? https://www.youtube.com/watch?v=NugRZGDbPFU

- From Reed, S., Sarasvathy, S., Dew, N., Wiltbank, R., \& Ohlsson, A. V. (2010). Effectual entrepreneurship. Taylor \& Francis.

○ Chapter 1, Entrepreneurs are visionaries. Myth

- Chapter 2, I don't have a good idea.

○ Chapter 3, Entrepreneurs are risk takers. Myth

- Chapter 4, I don't have enough money. Myth

○ Chapter 5, Entrepreneurs are extraordinary forecasters. Myth

- Chapter 6, I don't know how to take the plunge.

- Chapter 8, I am afraid of failing.

- Effectuation.org (register as an instructor to access videos)

○ Videos: 
Bird-in-Hand (Means)

Affordable Loss

$\circ \quad$ Crazy Quilt (Partnerships)

$\circ \quad$ Lemonade (Leverage Contingencies)

- Pilot-in-the-Plane (Control vs. Predict)

Ice Hotel (Brining Effectual Principles Together)

- *Entrepreneurial Aptitude Test (E.A.T.)

http://www.hsgl.com/entrepreneurial aptitude test overview.php

- *Video: What is locus of control?

http://psychology.about.com/od/personalitydevelopment/f1/What-Is-Locus-of-Control.htm

- *Video: Self-esteem, self-efficacy, and locus of control | Individuals and Society | MCAT |

Khan Academy https://www.youtube.com/watch?v=xcLK1PTG97k 
Developing Socially Conscious Practitioners: Supplementary File 1

\section{Supplementary File for article entitled "Business not as Usual: Developing Socially Conscious Entrepreneurs and Intrapreneurs" by Denise Linda Parris and Cecilia McInnis-Bowers}

Content Integrated in Self-Explorations and Class Discussion for Each Learning Module

*Module 5 (Self-Authorship) content is integrated in Modules 1-4 and are indicated by an asterisk.

Module 1: Redefine Business as a Force for Good—Responsible Business Management

- Business Skills for A Changing World https://netimpact.org/sites/default/files/documents/business-skills-changing-world-2011.pdf

- Ten Principles of the Global Compact https://www.unglobalcompact.org/what-is$\mathrm{gc} / \mathrm{mission} /$ principles

- Guide to Corporate Sustainability Report: Shaping a Sustainable Future https://www.unglobalcompact.org/docs/publications/UN_Global_Compact_Guide to_Corporat e Sustainability.pdf

- Video: History of the Global Compact https://www.youtube.com/watch?v=MQLXA1Nhjuo

- Video: Italian commercial explaining the Rationale for the UN Global Compact https://www.youtube.com/watch?v=hBRLRehpVY0

- Video: UN and private sector relationship to solve poverty https://www.youtube.com/watch?v=qK0Z3qeuiAM

- Video: Making global labor fair https://www.ted.com/talks/auret_van_heerden_making_global_labor_fair

- Video: Why focusing on shareholder value is bad for shareholders https://www.youtube.com/watch?v=fMNuDZYiqTY

- What is Corporate Social Responsibility? https://www.youtube.com/watch?v=E0NkGtNU 9w\&feature=youtu.be

- Introduction, chapter 1, 2, \& 3, The Triple Bottom Line, Savitz and Weber, JossyBass, 2006 
Developing Socially Conscious Practitioners: Supplementary File 2

- Video: Living the Legacy: The Milton Hershey Story, https://www.youtube.com/watch?v=cGlwqNaq-eo

- Video: What is the business case for sustainability? https://www.youtube.com/watch?v=K1W8WW0k3g

- Video: How does sustainability create value for a business? https://www.youtube.com/watch?v=jpeS91FDHpY

- The corporation as a force for good. Interview with Jeff Weiner, CEO LinkedIn, Inc. https://www.youtube.com/watch?v=H1T4bBhawZo\#t=35

- The Rise of the Social Entrepreneur, New York Times, David Bornstein http://opinionator.blogs.nytimes.com/2012/11/13/the-rise-of-socialentrepreneur/? php $=$ true \& type $=$ blogs\& $\mathrm{r}=01.3$

- 5 Lessons from Skoll on Social Entrepreneurship http://www.forbes.com/sites/johnrampton/2014/04/17/5-lessons-learned-from-skoll-worldforum-on-social-entrepreneurship/

- How do Social Entrepreneurs Revolutionize Industries? https://www.ashoka.org/sites/www.ashoka.org/files/2013-Impact-Study-FINAL-web.pdf

- Selected Social Entrepreneurship and Social Innovation Business Models:

○ Water for Waves http://www.wavesforwater.org/about/story

○ Clean the World https://cleantheworld.org

○ Rebuild Globally http://rebuildglobally.org/rebuild-globally/

○ IDignity http://www.idignity.org/about

○ BE Benevolent http://www.benevolent.net/index.html?view=success 
Developing Socially Conscious Practitioners: Supplementary File 3

- Chapter 20, Entrepreneurship as a technology for social change? From Read, S., Sarasvathy, S., Dew, N., Wiltbank, R., \& Ohlsson, A. V. (2010). Effectual entrepreneurship. Taylor \& Francis.

Module 2: Develop Business Knowledge through Practice-Management Decisions

- Introduction to Business Strategy: A Market Place Live Business Simulation http://www.marketplace-simulation.com/introduction-to-business-and-strategy

- *Keirsey’s Temperaments https://www.youtube.com/watch? v=j2z67HLV4ls

○ Temperament survey: http://www.keirsey.com/sorter/register.aspx

- *Emotional Intelligence Executive Briefing:

○ https://www.cu.edu/sites/default/files/ExecWorkingEI.pdf

○ http://www.talentsmart.com/about/emotional-intelligence.php

○ http://psychology.about.com/od/emotion/f/what-are-emotions.htm

○ http://psychology.about.com/od/emotion/tp/purpose-of-emotions.htm

- *Video: Emotional Intelligence by Daniel Goleman https://www.youtube.com/watch?v=n6MRsGwyMuQ

- *Video: Emotional Intelligence by Travis Bradberry https://www.youtube.com/watch?v=JziINJBG9Xo

- *Video: Leading with Emotional Intelligence in the Workplace https://www.youtube.com/watch?v=OoLVo3snNA0

Module 3: Engage in Entrepreneurial Mindsets and Processes-Collaborative Innovation

- What is Design Thinking? By Tim Brown, Harvard Business Review https://www.ideo.com/images/uploads/thoughts/IDEO_HBR_Design_Thinking.pdf 
Developing Socially Conscious Practitioners: Supplementary File 4

- Video: What is Design Thinking? By Daylight

- $\quad$ http://www.whatisdesignthinking.org/

- Bootcamp Bootleg from the d. School Hasso Plattner Institute of Design at Stanford

- $\quad$ https://dschool.stanford.edu/wp-content/uploads/2011/03/BootcampBootleg20s10v2SLIM.pdf

- *Video: The Essence of Leadership, Otto Scharmer

- $\quad$ https://www.youtube.com/watch?v=8sdIIx6eCbE\&list=PLWP7J8UaSOds04IK1KUjrXJPXINY $\underline{\mathrm{hK} 5 \mathrm{t} \& \text { index }}=1$

- *Theory U Executive Summary

- https://www.presencing.com/sites/default/files/page-files/Theory U Exec Summary.pdf

- *Four levels of listening, Otto Scharmer

- $\quad$ https://www.youtube.com/watch?v=eLfXpRkVZaI

- Video: What is HCDT? By Human Factors Research, https://www.youtube.com/watch?v=a7sEoEvT818

- Video: One week at IDEO-HCDT in 2 Minutes https://www.youtube.com/watch?v=xWmJRFur-SU

- Understanding the five Modes of HCDT (produced or curated by Florida Hospital Innovation Lab- FHIL)

- Video:_Empathy https://www.youtube.com/watch?v=10iJ7P2OtkU

- Video: Reframing by FHIL https://www.youtube.com/watch?v=Ca5Vu8iT6aI

- Video: Ideate by FHIL https://www.youtube.com/watch?v=8dm4iVWyOV0

- Video: Prototype by FHIL https://www.youtube.com/watch?v=FnJIJEUBLms

- Video: Test by FHIL https://www.youtube.com/watch?v=2me7pcteY5A

- Empathy on the Edge, Tim Brown, IDEO 
Developing Socially Conscious Practitioners: Supplementary File 5

- https://www.ideo.com/images/uploads/news/pdfs/Empathy_on the_Edge.pdf

- Ethnography for Empathy, Ellen Isaacs

- $\quad$ https://www.youtube.com/watch?v=nV0jY5VgymI

- Yes, And... for Empathy, Karen Tilstra, Director of the Florida Hospital Innovation Lab

- $\quad$ https://www.youtube.com/watch?v=11SK qNLx5U

\section{Module 4: Identifying and Creating Opportunities - Application of Effectuation}

- What makes entrepreneurs entrepreneurial? Sarasvathy, Saras D.

http://www.effectuation.org/sites/default/files/documents/what-makes-entrepreneursentrepreneurial-sarasvathy.pdf

- Video: Think like an innovator. https://www.youtube.com/watch?v=FSxSinVVRLw

- Video: Where do ideas come from? https://www.youtube.com/watch?v=NugRZGDbPFU

- From Reed, S., Sarasvathy, S., Dew, N., Wiltbank, R., \& Ohlsson, A. V. (2010). Effectual entrepreneurship. Taylor \& Francis.

- Chapter 1, Entrepreneurs are visionaries. Myth

- Chapter 2, I don't have a good idea.

- Chapter 3, Entrepreneurs are risk takers. Myth

- Chapter 4, I don't have enough money. Myth

- Chapter 5, Entrepreneurs are extraordinary forecasters. Myth

- Chapter 6, I don't know how to take the plunge.

- Chapter 8, I am afraid of failing.

- Effectuation.org (register as an instructor to access videos)

○ Videos: 
Developing Socially Conscious Practitioners: Supplementary File 6

Bird-in-Hand (Means)

Affordable Loss

$\circ \quad$ Crazy Quilt (Partnerships)

$\bigcirc \quad$ Lemonade (Leverage Contingencies)

○ Pilot-in-the-Plane (Control vs. Predict)

Ice Hotel (Brining Effectual Principles Together)

- *Entrepreneurial Aptitude Test (E.A.T.)

http://www.hsgl.com/entrepreneurial aptitude test overview.php

- *Video: What is locus of control?

http://psychology.about.com/od/personalitydevelopment/f1/What-Is-Locus-of-Control.htm

- *Video: Self-esteem, self-efficacy, and locus of control | Individuals and Society | MCAT |

Khan Academy https://www.youtube.com/watch?v=xcLK1PTG97k 